\title{
Long-term (2001-2012) trends of carbonaceous aerosols from a remote island in the western North Pacific: an outflow region of Asian pollutants
}

\author{
Suresh K. R. Boreddy ${ }^{1}$, M. Mozammel Haque ${ }^{1, \mathrm{a}}$, and Kimitaka Kawamura ${ }^{1, \mathrm{~b}}$ \\ ${ }^{1}$ Institute of Low Temperature Science, Hokkaido University, Sapporo 060-0819, Japan \\ anow at: Yale-NUIST Center on Atmospheric Environment, Nanjing University of Information Science and Technology, \\ Nanjing, 21004, China \\ ${ }^{\mathrm{b}}$ now at: Chubu Institute of Advanced Studies, Chubu University, Kasugai 487-8501, Japan
}

Correspondence: Kimitaka Kawamura (kkawamura@isc.chubu.ac.jp)

Received: 28 March 2017 - Discussion started: 5 April 2017

Revised: 25 November 2017 - Accepted: 20 December 2017 - Published: 31 January 2018

\begin{abstract}
The present study reports on long-term trends of carbonaceous aerosols in total suspended particulate (TSP) samples collected at Chichijima in the western North Pacific during 2001-2012. Seasonal variations of elemental carbon (EC), organic carbon (OC), and water-soluble organic carbon (WSOC) concentrations showed maxima in winter to spring and minima in summer. These seasonal differences in the concentrations of carbonaceous aerosols were associated with the outflows of polluted air masses from East Asia, which are clearly distinguishable from pristine air masses from the central Pacific. The higher concentrations of carbonaceous aerosols during winter to spring are associated with long-range atmospheric transport of East Asian continental polluted air masses, whereas lower concentrations may be due to pristine air masses from the central Pacific in summer. The annual trends of OC / EC $\left(+0.46 \% \mathrm{yr}^{-1}\right)$, WSOC $\left(+0.18 \% \mathrm{yr}^{-1}\right)$ and WSOC $/ \mathrm{OC}\left(+0.08 \% \mathrm{yr}^{-1}\right)$ showed significant $(p<0.05)$ increases during the period of 2001-2012, suggesting that photochemical formation of WSOC and its contributions to secondary organic aerosols (SOAs) have increased over the western North Pacific via long-range atmospheric transport. We found a significant increase $\left(+0.33 \% \mathrm{yr}^{-1}\right)$ in $\mathrm{nss}-\mathrm{K}^{+} / \mathrm{EC}$ ratios, demonstrating that concentrations of biomass-burning-derived carbonaceous aerosols have increased, while those of primary fossilfuel-derived aerosols have decreased over the western North Pacific. Further, secondary biogenic emissions are also important over the western North Pacific as inferred from a significant increase $\left(+0.14 \% \mathrm{yr}^{-1}\right)$ in the concentrations of
\end{abstract}

methanesulfonate ( $\mathrm{MSA}^{-}$, a tracer for biogenic sources). This point was further supported by a moderate correlation $(r=0.40)$ between WSOC and $\mathrm{MSA}^{-}$. We also found a significant increase in OC / TC (total carbon) and WSOC / TC ratios, further suggesting that photochemical formation of WSOC and its contributions to SOAs have increased over the western North Pacific during 2001-2012 via long-range atmospheric transport from East Asia.

\section{Introduction}

Particulate air pollution is one of the most important environmental issues due to its severe impact on visibility and air quality, and has been a great issue over East Asia, particularly in China (Zhang and Cao, 2015; Cui et al., 2015). On the other hand, its impacts on not only climate but also public health may be more severe and intricate (Pöschl, 2005; Menon et al., 2002). Carbonaceous aerosols are ubiquitous in the Earth's atmosphere and potentially cause harmful effect on human health (Bond et al., 2013; Kanakidou et al., 2005; Ramanathan and Carmichael, 2008; Fatima et al., 2012; Chung and Seinfeld, 2002). They are traditionally divided into two fractions: organic carbon (OC), which contains less volatile and more reflective species, and elemental carbon (EC; alternatively referred to as black carbon, BC), which is the least reflective and most light-absorbing component (Pöschl, 2005). However, the role of OC on cooling or 
warming has been a matter of debate (Chung et al., 2012; Cazorla et al., 2013) because a class of OC (brown carbon) may absorb sunlight (Feng et al., 2013; Lu et al., 2015; Laskin et al., 2015; Bahadur et al., 2012). In the ambient atmosphere, however, these two fractions (EC and OC) are mixed and consequently complicate the estimation of net radiative forcing (Jacobson, 2001). Therefore, studying carbonaceous aerosols and their sources is essential to understand how the different sources of carbonaceous particles may influence the radiative balance on a regional and global scale.

The major sources of carbonaceous aerosols are fossil fuel and biomass burning in addition to the atmospheric oxidation of anthropogenic and biogenic volatile organic compounds (VOCs) (Chung et al., 2012; Szidat et al., 2006). The global emission of organic aerosols (OAs) from biomass and fossil fuel sources has been estimated at 45-80 and 10$30 \mathrm{Tg} \mathrm{yr}^{-1}$, respectively (Scholes and Andreae, 2000). Due to the presence of polar functional groups, particularly carboxylic acids, many organic compounds in OA are watersoluble (Boreddy et al., 2016) and hence aid the particles acting as cloud condensation nuclei (CCN) (Novakov and Penner, 1993; Matsumoto et al., 1997; Asa-Awuku et al., 2009). According to the recent report of the intergovernmental panel on climate change (IPCC, 2013), the radiative forcing of BC and $\mathrm{OA}$ associated with fossil fuel and biofuel combustions is in the range of +0.05 to +0.8 (mean: +0.4$) \mathrm{W} \mathrm{m}^{-2}$ and -0.4 to $-0.1(-0.12) \mathrm{W} \mathrm{m}^{-2}$, respectively. It is $+0.0(-0.2$ to $+0.2) \mathrm{W} \mathrm{m}^{-2}$ as a result of their change offset when $\mathrm{BC}$ and OA are emitted by biomass burning (Boucher et al., 2013). Therefore, carbonaceous aerosols have a net warming effect on the climate as per the IPCC 2013 report. However, there still exist large uncertainties in quantifying radiative forcing of carbonaceous aerosols, particularly with regard to OA (Reddy and Boucher, 2004).

The atmosphere over East Asia is becoming worse due to not only the dense population but also rapid urbanization/industrialization (Fu et al., 2012; Cao et al., 2007). On a global scale, China has the largest carbonaceous aerosol emissions from combustion with contributions of about 24 and $30 \%$ for OC and BC, respectively (Bond et al., 2004). Recently, Wang et al. (2016) suggested that coal combustions and vehicular emissions are the dominating sources of carbonaceous aerosols in China (Kirillova et al., 2014). Using the emission estimated by Model of Emissions of Gases and Aerosols from Nature (MEGAN) and combined with the MOdel of HYdrocarbon Emissions from the CANopy (MOHYCAN), Stavrakou et al. (2014) reported an increased emission of biogenic isoprene over Asia $\left(0.16 \% \mathrm{yr}^{-1}\right)$ with more pronounced trend over China $\left(0.52 \% \mathrm{yr}^{-1}\right)$ during 1979-2012. In contrast, $\mathrm{SO}_{2}$ emissions over China have been declining since 2006 because of the wide usage of flue-gas desulfurization (FGD) equipment in power plants (Lu et al., 2010, 2011). All these East Asian pollutants along with soil dust are transported to the North Pacific via long-range atmospheric transport by westerly winds and perturb the remote

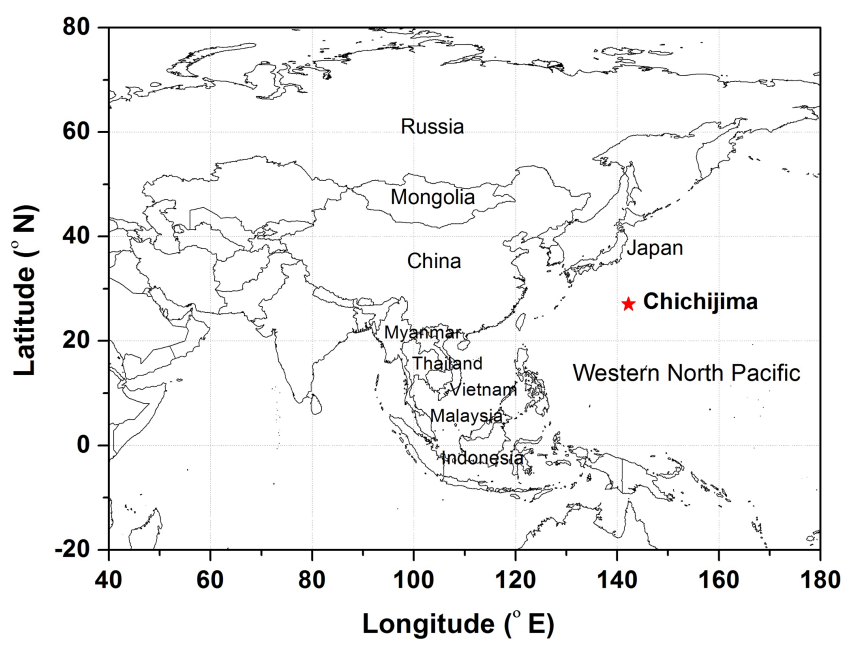

Figure 1. Location of sampling site (indicated by red star) in the western North Pacific and its adjacent Asian countries.

marine background conditions and the ocean biogeochemistry by heterogeneous reactions (Boreddy et al., 2015; Matsumoto et al., 2004). In addition to East Asian pollutants, the western North Pacific also receives biomass burning emissions from Southeast Asia (Tsay et al., 2016; Lin et al., 2013; Huang et al., 2013).

To better understand the long-range transport of Asian pollutants and their atmospheric processing over the western North Pacific, we continuously collect total suspended particulate (TSP) samples since 1990 at Chichijima (Mochida et al., 2003; Kawamura et al., 2003; Boreddy and Kawamura, 2016). Chichijima is a remote marine island in the western North Pacific, which is located in the outflow region of East Asian pollutants and dust during the westerly wind season and in the pristine air masses under the wind regime of easterlies. This island is about $1000 \mathrm{~km}$ south of Tokyo, Japan, and $2000 \mathrm{~km}$ from the East Asian countries (China) as shown in Fig. 1. Therefore, the observation at Chichijima is useful for studying the long-range transport of East Asian pollutants and their heterogeneous chemistry over the western North Pacific (Boreddy et al., 2014; Verma et al., 2015). In this study, we discuss the long-term trends in the concentrations of carbonaceous aerosols (EC, OC, and water-soluble organic carbon (WSOC)) and their ratios during 2001-2012 in addition to seasonal variations. The role of photochemical oxidation of anthropogenic and biogenic VOCs on OC and WSOC and their relations to $\mathrm{CCN}$ are also discussed. 


\section{Instrumentation and data analyses}

\subsection{Sampling site and aerosol collection}

Figure 1 shows the location of the sampling site and its adjacent Asian countries in the western North Pacific. TSP samples were collected at the Satellite Tracking Centre of the Japan Aerospace Exploration Agency (JAXA, elevation: $254 \mathrm{~m})$ in Chichijima $\left(27^{\circ} 04^{\prime} \mathrm{N}, 142^{\circ} 13^{\prime} \mathrm{E}\right)$ on a weekly basis (Boreddy and Kawamura, 2015). Aerosol samples are collected on pre-combusted $\left(450^{\circ} \mathrm{C}\right.$ for $\left.3-5 \mathrm{~h}\right)$ quartz filter $(20 \mathrm{~cm} \times 25 \mathrm{~cm}$, Pallflex 2500QAT-UP) using a high-volume air sampler (HVS) with a flow rate of $1 \mathrm{~m}^{3} \mathrm{~min}^{-1}$. The HVS was installed at a height of $5 \mathrm{~m}$ above the ground level. The filters were placed in a pre-baked $\left(450{ }^{\circ} \mathrm{C}\right.$ for $\left.6 \mathrm{~h}\right)$ glass jar $(150 \mathrm{~mL})$ with a Teflon-lined screw cap before sample collection. After aerosol collection, the filters were recovered into the glass jar, transported to the laboratory in Hokkaido University, Sapporo, and stored in a freezer room at $-20^{\circ} \mathrm{C}$ prior to analysis. A total of 545 aerosol samples and about 56 field blank samples were used for the analysis of carbonaceous components during 2001-2012.

\subsection{Analyses of carbonaceous aerosols}

Concentrations of OC and EC were determined using a Sunset Laboratory carbon analyzer following the IMPROVE (Interagency Monitoring of Protected Visual Environments) thermal-optical evolution protocol (Wang et al., 2005), assuming carbonate carbon (CC) in the aerosol samples to be insignificant (Chow and Watson, 2002). Previous studies have also shown that carbonate, particularly calcium carbonate, levels were low or negligible in most ambient samples, which were analyzed using the IMPROVE protocol (Wang et al., 2005; Clarke and Karani, 1992; Chow et al., 2001). A filter cut of $1.54 \mathrm{~cm}^{2}$ of each filter was placed in a quartz tube inside the thermal desorption chamber of the analyzer and then stepwise heating was applied. Helium (He) gas was applied in the first ramp and was switched to mixture of $\mathrm{He} / \mathrm{O}_{2}$ in the second ramp. The evolved $\mathrm{CO}_{2}$ during the oxidation at each temperature step was measured by non-dispersive infrared (NDIR) detector system. The calculated detection limits of OC and EC were 0.05 and $0.02 \mu \mathrm{gC} \mathrm{m}^{-3}$, respectively. The sum of $\mathrm{OC}$ and $\mathrm{EC}$ was considered to as total carbon (TC) in this study.

To determine WSOC, a punch of $20 \mathrm{~mm}$ in diameter of each filter was extracted with $20 \mathrm{~mL}$ organic-free ultrapure water ( $>18.2 \mathrm{M} \Omega \mathrm{cm}$, Sartorius arium 611 UV) and ultrasonicated for $30 \mathrm{~min}$. These extracts were passed through a disk filter (Millex-GV, $0.22 \mu \mathrm{m}$ pore size, Millipore) to remove the filter debris and insoluble particles and analyzed using a total organic carbon (TOC) analyzer (Shimadzu, TOC$\mathrm{Vcsh}$ ) equipped with a catalytic oxidation column and nondispersive infrared detector (Miyazaki et al., 2011).
Concentrations of water-soluble methanesulfonate $\left(\mathrm{MSA}^{-}\right)$, non-sea-salt sulfate (nss- $\left.\mathrm{SO}_{4}^{2-}\right)$, non-sea-salt potassium $\left(\mathrm{nss}-\mathrm{K}^{+}\right)$, and sodium $\left(\mathrm{Na}^{+}\right)$were taken from the study of Boreddy and Kawamura (2015), in order to support the inferences related to carbonaceous species over the western North Pacific, which were determined using ion chromatography (761 Compact IC, Metrohm, Switzerland).

The analytical errors in the replicate analyses were less than $10 \%$ for OC, EC, and WSOC in this study. The concentrations of carbonaceous aerosols reported in this study were corrected for field blanks. The levels of blanks were less than $5 \%$ for all the parameters in real samples.

\subsection{Statistical analyses}

Two statistical approaches were used to better conduct the trend analyses in time series of WSOC, EC, and OC and their ratios during 2001-2012. First, the tendency (linear trend) equation was used for each time series (Draper and Smith, 1966). Second, all trends were assessed by using the MannKendall non-parametric test (Mann, 1945; Kendall, 1975), which is completely independent of the first approach. More detailed information about these statistical analyses are described in the Supplement.

\section{Results and discussion}

\subsection{Air mass back trajectories and general meteorology}

To better understand the influence of heterogeneity in air masses to carbonaceous aerosols, we computed daily 7-day isentropic air mass back trajectories at an altitude of $500 \mathrm{~m}$ for each month using a Hybrid Single Particle LagrangianIntegrated Trajectory (HYSPLIT) model (Draxler and Rolph, 2013) during 2001-2012 as shown in Fig. 2. We also investigated the MODerate resolution Imaging Spectroradiometer (MODIS)-derived fire count data along with the back trajectories to understand the intensity of biomass burning over East Asia and South/Southeast Asia. Fire spot data were downloaded from the MODIS website over the region (80 to $150^{\circ} \mathrm{E}, 10^{\circ} \mathrm{S}$ to $\left.70^{\circ} \mathrm{N}\right)$ during the year 2001 as an example for all the years (2001-2012) because of overlapping (there is no much difference in the intensity and area of fire spots). More detailed information about the monthly air mass back trajectories and fire data for each year during 20012012 are described elsewhere (Verma et al., 2015). From winter (December-February) to spring (March-May), the air masses carry continental air pollutants and dusts from East Asia to the sampling site in the Pacific by a long-range atmospheric transport (Fig. 2). The continental air masses are absent in summer (June to August) with the pristine air masses coming from the central Pacific to the observation site. In autumn (September-November), the air mass pattern shifts from southeasterly to northwesterly with stronger winds towards winter. 


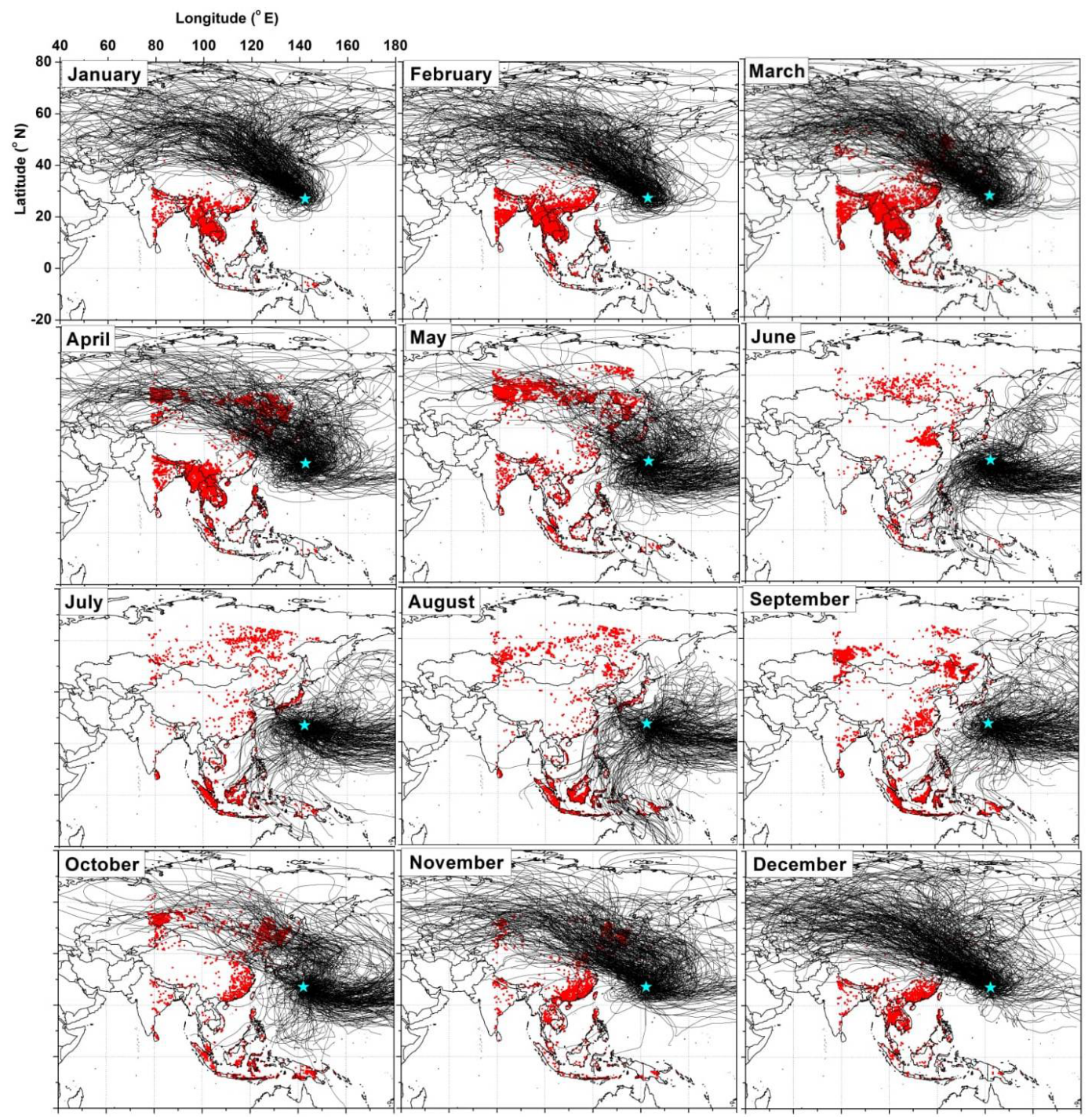

Figure 2. Seven-day daily air mass back trajectories at $500 \mathrm{~m}$ a.g.1. computed using HYSPLIT model for each month during 2001-2012 at Chichijima in the western North Pacific. The star symbol indicates the sampling site and red dots represent the MODIS inferred fire spots. Fire spots were downloaded for the region $\left(80-150^{\circ} \mathrm{E},-10-70^{\circ} \mathrm{N}\right)$ during the year 2001.

Figure S1 in the Supplement shows the temporal variations of meteorological parameters such as air temperature $\left({ }^{\circ} \mathrm{C}\right)$, relative humidity $(\%)$, wind speed $\left(\mathrm{m} \mathrm{s}^{-1}\right)$, and precipitation (mm) at Chichijima during the study period of 20012012. All the meteorological parameters were downloaded from the Japan Meteorological Agency (JMA). There was a clear seasonal variation in ambient temperature, relative humidity, and precipitation with summer maxima and winter minima. Wind speeds were higher in winter to spring and lower in summer.

\subsection{Monthly/seasonal variations}

Figure 3a-f present the monthly/seasonal variations in the concentrations of EC, OC, WSOC, and some specific mass ratios at Chichijima in the western North Pacific during 2001-2012. The corresponding statistical data were reported in Table 1. All measured species (EC, OC, and WSOC) clearly showed winter-to-spring maxima (highest concentration was in March) and summer minima (lowest in July) and then increase towards autumn. The seasonal variation in carbonaceous aerosols observed in this study was found consistent with the typical seasonal pattern in ambient carbonaceous aerosols over China (X. Y. Zhang et al., 2008; Cao et al., 2006), indicating a common source for these components, which are long-range-transported to the western North Pacific. This, of course, can also be influenced by seasonal meteorology and air mass back trajectories over the western North Pacific as discussed in Sect. 3.1. 
Table 1. Monthly mean ( \pm standard deviation) values of EC, OC, WSOC concentrations, and their ratios during 2001-2012 over the western North Pacific.

\begin{tabular}{lrrrrrr}
\hline Month & $\begin{array}{r}\mathrm{EC} \\
\left(\mu \mathrm{g} \mathrm{m}^{-3}\right)\end{array}$ & $\begin{array}{r}\text { OC } \\
\left(\mu \mathrm{g} \mathrm{m}^{-3}\right)\end{array}$ & $\begin{array}{r}\text { WSOC } \\
\left(\mu \mathrm{g} \mathrm{m}^{-3}\right)\end{array}$ & OC / EC & WSOC / OC & nss-K $^{+} / \mathrm{EC}$ \\
\hline January & $0.18 \pm 0.07$ & $0.80 \pm 0.41$ & $0.54 \pm 0.28$ & $4.85 \pm 2.01$ & $0.69 \pm 0.14$ & $0.29 \pm 0.16$ \\
February & $0.25 \pm 0.07$ & $0.95 \pm 0.36$ & $0.55 \pm 0.17$ & $3.95 \pm 1.31$ & $0.63 \pm 0.22$ & $0.35 \pm 0.39$ \\
March & $0.28 \pm 0.05$ & $1.13 \pm 0.37$ & $0.59 \pm 0.22$ & $4.11 \pm 1.19$ & $0.56 \pm 0.19$ & $0.22 \pm 0.09$ \\
April & $0.22 \pm 0.10$ & $0.77 \pm 0.32$ & $0.48 \pm 0.28$ & $3.89 \pm 1.37$ & $0.62 \pm 0.20$ & $0.26 \pm 0.12$ \\
May & $0.14 \pm 0.08$ & $0.80 \pm 0.31$ & $0.35 \pm 0.19$ & $7.68 \pm 4.11$ & $0.44 \pm 0.19$ & $0.40 \pm 0.27$ \\
June & $0.08 \pm 0.07$ & $0.74 \pm 0.35$ & $0.30 \pm 0.18$ & $21.1 \pm 30.4$ & $0.44 \pm 0.17$ & $0.54 \pm 0.36$ \\
July & $0.06 \pm 0.06$ & $0.58 \pm 0.35$ & $0.22 \pm 0.07$ & $19.0 \pm 16.7$ & $0.44 \pm 0.17$ & $0.97 \pm 0.94$ \\
August & $0.04 \pm 0.03$ & $0.63 \pm 0.27$ & $0.27 \pm 0.16$ & $33.2 \pm 52.5$ & $0.46 \pm 0.23$ & $0.70 \pm 0.69$ \\
September & $0.05 \pm 0.04$ & $0.60 \pm 0.26$ & $0.20 \pm 0.10$ & $22.3 \pm 17.3$ & $0.38 \pm 0.19$ & $1.02 \pm 0.82$ \\
October & $0.08 \pm 0.04$ & $0.62 \pm 0.18$ & $0.27 \pm 0.12$ & $12.2 \pm 9.07$ & $0.45 \pm 0.19$ & $0.50 \pm 0.43$ \\
November & $0.15 \pm 0.10$ & $0.75 \pm 0.39$ & $0.42 \pm 0.20$ & $6.68 \pm 4.89$ & $0.61 \pm 0.20$ & $0.44 \pm 0.26$ \\
December & $0.18 \pm 0.09$ & $0.73 \pm 0.29$ & $0.39 \pm 0.08$ & $4.63 \pm 1.65$ & $0.59 \pm 0.18$ & $0.21 \pm 0.12$ \\
\hline
\end{tabular}
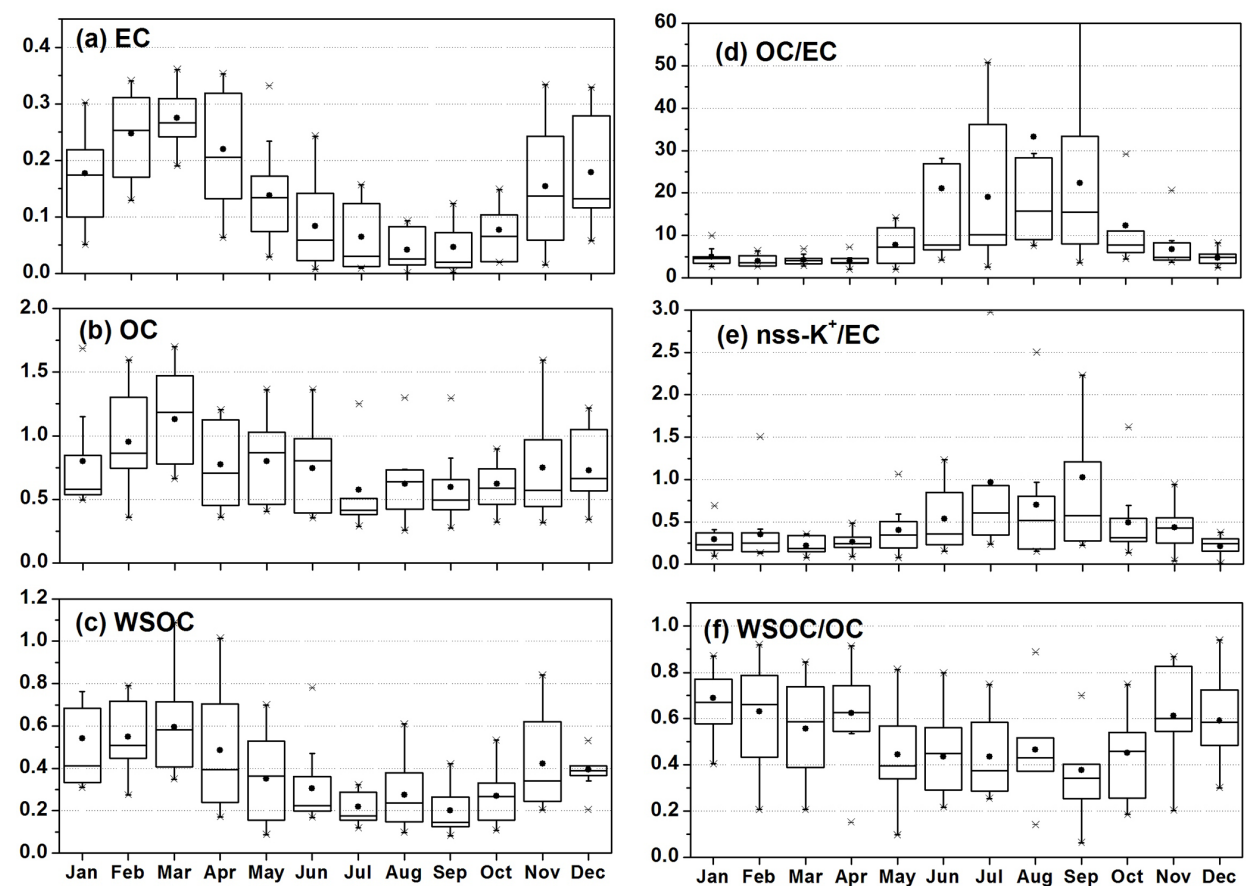

Figure 3. Box-and-whisker plots of monthly variations of carbonaceous aerosol components $\left(\mu \mathrm{g} \mathrm{m}^{-3}\right)$ and some specific mass ratios at Chichijima in the western North Pacific during 2001-2012. The horizontal line and small dot inside the box indicate median and mean, respectively. The vertical hinges represent data points from the lower to the upper quartile (i.e., 25th and 75th percentiles). The whiskers represent data points from the 1st to 99th percentiles.

Relatively higher monthly average concentrations up to $0.28,1.13$, and $0.59 \mu \mathrm{g} \mathrm{m}^{-3}$ were observed for EC, OC, and WSOC in March. In contrast, their monthly averages were lower in summer or early autumn (July or September) with the concentrations of $0.04,0.58$, and $0.20 \mu \mathrm{g} \mathrm{m}^{-3}$, respectively (Table 1). It is well documented that in summer, a maritime high-pressure wind dominates over the western North Pacific in which the air masses are pristine and less influenced by the continental outflow from East Asia (Fig. 2).
This observation is consistent with the fact that concentrations of anthropogenic nss- $\mathrm{SO}_{4}^{2-}, \mathrm{NO}_{3}^{-}, \mathrm{NH}_{4}^{+}$, and nss$\mathrm{K}^{+}$showed similar seasonal variations with winter and/or spring maxima and summer minima (Boreddy and Kawamura, 2015). On the other hand, continental air masses blow from the Asian continent in winter and spring; therefore, the maritime background condition of the western North Pacific is often influenced by the continental outflow via longrange atmospheric transport (Duce et al., 1980). Very low 
Table 2. Literature values of OC / EC ratios for various sources of aerosol. Different font styles indicate different OC / EC values from different studies.

\begin{tabular}{lll}
\hline Source of aerosol & OC / EC ratio & References \\
\hline Fossil fuel combustion & $4.0, \mathbf{4 . 1}, 1.1$ & Koch (2001), Cao et al. (2005), Watson et al. (2001) \\
Coal combustion & $2.7,12.0$ & Watson et al. (2001), Cao et al. (2005) \\
Biomass burning & $9.0, \mathbf{6 0 . 3}, 5-8$ & Cachier et al. (1989), Cao et al. (2005), Andreae and Merlet (2001) \\
Forest fire & $\sim 16.0$ & Watson et al. (2001) \\
Diesel truck plume & $0.06,0.8, \mathbf{0 . 3}$ & Dallmann et al. (2014), Na et al. (2004), Turpin and Huntzicker (1995) \\
Gasoline vehicle & $0.02,2.2$ & Dallmann et al. (2014), Na et al. (2004) \\
Secondary organic carbon & 3.3 & Saarikoski et al. (2008) \\
Long-range transported/aged & 12.0 & Saarikoski et al. (2008) \\
Traffic & 0.7 & Saarikoski et al. (2008) \\
Cooking emissions & $4.3-7.7$ & See and Balasubramanian (2008) \\
\hline
\end{tabular}

concentrations of EC in summer, whose abundances were up to 7 times lower than those in the continental outflow, suggest negligible contribution of local anthropogenic emissions as well as long-range influences over the sampling site. These results are consistent with previous studies, which reported that several times lower concentrations of organic compounds in summer compared to winter/spring over the same observation site (Kawamura et al., 2003; Mochida et al., 2003). Therefore, it is reasonable to believe that the sources of carbonaceous aerosols were transported from the adjacent Asian countries to the western North Pacific via long-range atmospheric transport.

As described earlier, EC particles are primary and predominately come from biomass and fossil fuel combustion sources. Conversely, OC is of either primary origin or secondary formation via gas-to-particle conversion and heterogeneous phase processing in the atmosphere. The precursors of secondary OC may also come from biogenic sources in addition to fossil fuel combustion and biomass burning emissions. The OC / EC ratios often used to distinguish the relative contribution of primary vs. secondary sources as well as biomass vs. fossil fuel burning sources (Turpin and Huntzicker, 1995; Castro et al., 1999; Rastogi et al., 2016). Atmospheric aerosols emitted from fossil fuel combustion are characterized by lower OC / EC ratios $(<2.0)$, whereas higher OC / EC ratios ( $>2.0$ ) have been used to point out the presence of secondary OA (SOA) (Cao et al., 2003; Chow et al., 1996; Kunwar and Kawamura, 2014; Pani et al., 2017) in the atmosphere with a limited impact of biomass burning. Table 2 summarizes OC / EC ratios reported for various sources of aerosol particles. The split of OC / EC ratios at higher or lower than 2 (from Table 2) may not be the best indicator of SOA because fossil fuel combustion has OC / EC of 1.1 (Watson et al., 2001), 4.0 (Koch et al., 2001), and 4.1 (Cao et al., 2005). Monthly mean OC / EC ratios in this study are much larger in the summer and still greater than the cutoff $(\sim 4.0)$ in winter to spring as shown in Table 1. This result suggests a dominance of SOA over the western North Pacific. The seasonal variation of OC / EC mass ratios showed max- ima in summer ( $\sim 21$ to 33$)$ and minima in winter to spring (3.9 to 7.7). The extremely high OC / EC ratios in summer indicate the secondary formation of OC via oxidation processes, while low OC / EC ratios in winter to spring suggests that both biomass burning and fossil fuel combustion contribute to carbonaceous aerosols over the western North Pacific in winter to spring.

It is well documented that nss- $\mathrm{K}^{+}$and EC can be used as tracers for biomass burning and fossil fuel combustion emissions, respectively. Therefore, $\mathrm{nss}^{-} \mathrm{K}^{+} / \mathrm{EC}$ ratios were widely used to better identify major sources of carbonaceous aerosols (Wang et al., 2005; Rastogi et al., 2016; Ram and Sarin, 2011). The higher nss- $\mathrm{K}^{+} / \mathrm{EC}$ ratios $(>0.20)$ indicate the dominance of biomass burning emissions, whereas lower ratios $(<0.10)$ suggest the prevalence of fossil fuel combustion emissions. In this study, higher $n s s-\mathrm{K}^{+} / \mathrm{EC}$ mass ratios were observed in midsummer (July) to early autumn (September) (Fig. 3e), suggesting an influence of biomass burning emissions from southeast Asian countries via long-range atmospheric transport over the western North Pacific. This point is consistent with the air mass back trajectory and MODIS fire count data during summer months (Fig. 2), which clearly showed that air masses were occasionally coming from Southeast Asia (Indonesia, Malaysia and New Guinea, etc.) where biomass burning is a common phenomena during summer to early autumn. Biomass burning products were transported to the western North Pacific (Fig. 2). Verma et al. (2015) reported significant concentrations of levoglucosan during summer in Chichijima (in the absence of East Asian outflows), which were attributed to the occasional transport of biomass burning influenced air masses from southeast Asia, as inferred from the air mass trajectories and fire spot data during 2001-2013. Therefore, carbonaceous aerosols over Chichijima strictly follow the seasonal wind patterns in the western North Pacific.

Previous studies have shown that SOA is largely composed of oxygenated compounds that are highly watersoluble (Kanakidou et al., 2005; Kondo et al., 2007, and references therein). Thus, measurements of WSOC have been 
used to estimate the SOA in ambient aerosols (Weber et al., 2007; Snyder et al., 2009; Sudheer et al., 2015; Decesari et al., 2001; Docherty et al., 2008). Because a major fraction of biomass burning products is highly water-soluble (Sannigrahi et al., 2006; Saarikoski et al., 2008), higher WSOC / OC ratios under ambient conditions with limited biomass burning impact have been used to better understand the photochemical activity and/or aging of aerosols and to discuss SOA formation mechanism in the atmosphere during long-range transport (Miyazaki et al., 2007; Ram et al., 2010b; Ram and Sarin, 2011; Kondo et al., 2007; Weber et al., 2007). The WSOC / OC ratios exceeding 0.4 have been used to indicate the significant contribution of SOA (Ram et al., 2010a) and aged aerosols. The WSOC / OC ratios ranged from 0.06 to 0.19 in diesel particles (Cheung et al., 2009) and 0.27 for vehicular emissions (Saarikoski et al., 2008).

In this study, we found that monthly mean WSOC / OC ratios were $>4.0$ for all months except for September, indicating a significant contribution from SOA over the western North Pacific. The seasonal variation of WSOC / OC showed higher values (monthly mean: 0.44 to 0.62 ) during winter to spring months (Fig. 3f), implying that SOA formation was enhanced due to an increased photochemical activity and/or aging of East Asian polluted aerosols during long-range atmospheric transport. The high WSOC / OC ratios are traditionally attributed to the atmospheric oxidation of various VOCs in the presence of oxidants such as ozone and hydroxyl radicals via gas- and/or aqueous-phase reactions in the atmosphere (Miyazaki et al., 2007; Ram and Sarin, 2012). However, the atmosphere over the western North Pacific is always characterized by high relative humidity $(>80 \%)$ and air temperature $\left(\sim 24^{\circ} \mathrm{C}\right)$ during the whole year (Fig. S1). Therefore, higher WSOC concentrations in winter to spring over the western North Pacific were largely attributed to the aqueous-phase oxidation of anthropogenic and/or biogenic VOCs (Youn et al., 2013), which are emitted over continental East Asia and long-range-transported to the western North Pacific.

On the other hand, we found lower ratios of WSOC / OC in summer. This result may suggest a minor contribution of water-soluble organic matter in summer due to a negligible contribution of aged continental air masses and/or significant contribution from marine biota. Based on the gradient flux measurements, Ceburnis et al. (2008) found that water-insoluble organic matter (WIOM) exhibited an upward flux, whereas water-soluble organic matter (WSOM) exhibited a downward flux, suggesting a primary production for WIOM and a secondary formation for WSOM. In this study, WIOM/WSOM ratios were higher in summer (mean: $1.45 \pm 0.17)$ and autumn $(0.35 \pm 0.57)$ than in winter $(0.19 \pm 0.67)$ as shown in Fig. 4a. Higher ratios of WIOM/WSOM in summer over the western North Pacific are consistent with an idea that the ocean-derived organic matter is emitted from the ocean surface via sea-to-air flux as a fresh (less aged) organic matter. This result is further supported by (a)

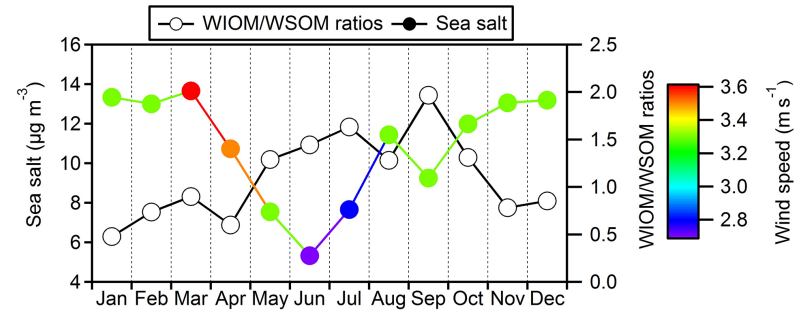

(b)

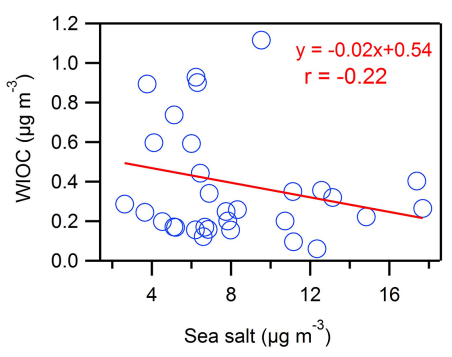

Figure 4. Monthly variations (a) WSIM / WSOM mass ratios and sea salt concentrations and (b) regression analysis between waterinsoluble organic carbon (WIOC) and sea salt concentrations. The color scale in (a) indicates the wind speed over the western North Pacific.

the study of Miyazaki et al. (2010), who reported a significant amount of WIOM in the western North Pacific during summer, which may be produced by bubble-bursting processes at the ocean surface. Similarly, Ovadnevaite et al. (2011) reported higher contributions of primary organic matter to marine aerosols over the northeast Atlantic.

Further, laboratory studies have revealed a high abundance of primary organic matter dominated by WIOM in marine aerosols (Facchini et al., 2008; Keene et al., 2007). However, it should be noted that although bubble-bursting process is a common source for both sea salt (sea salt $=3.2 \times \mathrm{Na}^{+}$, where 3.2 is the conservative mass ratio of salinity to $\mathrm{Na}$ in seawater; data obtained from Boreddy and Kawamura, 2015) and WIOM in marine aerosols, we found a negative/no correlation $(r=-0.22)$ between sea salt and water-insoluble organic carbon (WIOC) concentrations in summer (Fig. 4b). This result suggests an additional source of organic matter (completely independent of sea salt production and wind speed) which is evidenced by the higher $\mathrm{MSA}^{-} / \mathrm{nss}_{-} \mathrm{SO}_{4}^{2-}$ mass ratios (Boreddy and Kawamura, 2015) and higher concentrations of azelaic acid (Boreddy et al., 2017) during summer and autumn. $\mathrm{MSA}^{-} / \mathrm{nss}-\mathrm{SO}_{4}^{2-}$ mass ratios have been suggested as an indicator for the relative contribution of oceanic dimethyl sulfide (DMS) vs. anthropogenic sources to sulfate (Gondwe et al., 2004; Savoie and Prospero, 1989). Higher ratios indicate that nss- $\mathrm{SO}_{4}^{2-}$ is derived from the atmospheric oxidation of oceanic DMS, while lower ratios suggest the anthropogenic contribution of $\mathrm{SO}_{2}$. On the other hand, azelaic acid is a specific photochemical oxidation product of unsaturated fatty acids emitted from the ocean surface 
Table 3. Statistical report on the annual trends in carbonaceous aerosols and their ratios during 2001-2012 at Chichijima in the western North Pacific.

\begin{tabular}{lrrrr|rrr}
\hline \multirow{2}{*}{ Species } & \multicolumn{3}{c|}{ Concentrations $\left(\mu \mathrm{g} \mathrm{m}^{-3}\right)$} & \multicolumn{3}{|c}{ Mann-Kendall non-parametric test } \\
\cline { 2 - 8 } & Min & Max & Mean & SD & Kendall's tau $(\tau)$ & $p$ value & Sen's slope \\
\hline EC & 0.00 & 0.36 & 0.14 & 0.10 & -0.06 & $>0.05$ & -0.0002 \\
OC & 0.26 & 1.70 & 0.76 & 0.36 & 0.07 & $>0.05$ & 0.0008 \\
TC & 0.28 & 2.01 & 0.90 & 0.43 & 0.05 & $>0.05$ & 0.0007 \\
WSOC & 0.08 & 1.30 & 0.38 & 0.22 & $0.09^{*}$ & $>0.05$ & 0.0006 \\
OC / EC & 1.91 & 67 & 9.74 & 21.9 & $0.21^{*}$ & $<0.05$ & 0.0240 \\
WSOC / OC & 0.06 & 0.94 & 0.53 & 0.21 & $0.09^{*}$ & $<0.05$ & 0.0007 \\
OC / TC & 0.66 & 1.00 & 0.85 & 0.08 & $0.21^{*}$ & $<0.05$ & 0.0007 \\
EC / TC & 0.00 & 0.34 & 0.15 & 0.08 & -0.21 & $>0.05$ & -0.0007 \\
WSOC / TC & 0.06 & 0.86 & 0.44 & 0.17 & $0.14^{*}$ & $<0.05$ & 0.0009 \\
MSA $^{-}$ & 0.00 & 0.05 & 0.02 & 0.01 & $0.08^{*}$ & $<0.05$ & 0.00002 \\
nss-K $^{+} /$EC & 0.02 & 2.97 & 0.51 & 0.40 & $0.09^{*}$ & $<0.05$ & 0.0009 \\
\hline
\end{tabular}

“*” indicates that the trends are significant at $p<0.05$ level.

(Kawamura and Sakaguchi, 1999) and also found in biomass burning plumes (Graham et al., 2002). Therefore, it is worthy to note that, although marine biogenic sources are major contributors to organic matter during summer to autumn, there are some influence from non-marine sources (for example, transport of biomass burning products from Southeast Asia as suggested by higher ratios of $n s s-\mathrm{K}^{+} / \mathrm{EC}$ in summer), mixed with marine sources.

\subsection{Annual trends}

Figure 5 shows the annual trends in the concentrations of $\mathrm{EC}, \mathrm{OC}, \mathrm{TC}(\mathrm{EC}+\mathrm{OC})$, WSOC, and WSOC / OC ratios during the period of 2001-2012 over the western North Pacific (see Fig. S2 for annual mean variations). Table 3 summarizes the results of the statistical analyses. All the annual trends of chemical species and WSOC / OC ratios seem to present clear seasonal patterns with higher values in winter-spring and lower values in summer. On the other hand, seasonal variations of the $\mathrm{OC} / \mathrm{EC}$ and $\mathrm{nss}-\mathrm{K}^{+} / \mathrm{EC}$ ratios showed higher values in summer.

As seen from Fig. 5a-b and Table 3, concentrations of EC, OC, and TC during 2001-2012 ranged from 0.001 to $0.36 \mu \mathrm{g} \mathrm{m}^{-3}$ (mean: $0.142 \mu \mathrm{g} \mathrm{m}^{-3}$ ), 0.25 to $1.7 \mu \mathrm{g} \mathrm{m}^{-3}$ $\left(0.76 \mu \mathrm{g} \mathrm{m}^{-3}\right)$ and 0.28 to $2.01 \mu \mathrm{g} \mathrm{m}^{-3}\left(0.90 \mu \mathrm{g} \mathrm{m}^{-3}\right)$, respectively. The annual variations of EC showed a decreasing trend $\left(-0.007 \% \mathrm{yr}^{-1}\right)$, while $\mathrm{OC}$ and $\mathrm{TC}$ trends are continuously increasing $\left(+0.16\right.$ and $+0.11 \% \mathrm{yr}^{-1}$, respectively) from 2001 to 2012 although the rates were not significant $(p>0.05)$. However, the annual trends of OC / EC and OC / TC ratios increased significantly $(p<0.05 ;+0.46$ and $+0.06 \% \mathrm{yr}^{-1}$ ) from 2001 to 2012 (Fig. 5d and e), suggesting that the contribution of primary fossil fuel combustion to carbonaceous aerosols has declined during the sampling period. This point is supported by the annual trend of nss- $\mathrm{K}^{+} / \mathrm{EC}$ mass ratios, which showed a significant increase $(p<0.05$;
$+0.33 \% \mathrm{yr}^{-1}$ ) during the sampling period (Fig. $5 \mathrm{~g}$ ). This observation is consistent with the study of Verma et al. (2015), who observed a significant enhancement of levoglucosan (a good biomass burning tracer, e.g., Simoneit, 2002) during 2006-2013 over the sampling site. Therefore, all these results demonstrate that the contributions of biomass burning emissions to carbonaceous aerosols have increased significantly over the western North Pacific whereas the contributions of fossil fuel combustion have decreased.

Previous studies suggested that SOA is largely composed of water-soluble organic matter (Weber et al., 2007; Kondo et al., 2007). In this study, the annual trend of WSOC showed a significant increase $\left(p<0.05 ;+0.18 \% \mathrm{yr}^{-1}\right)$ from 2001 to 2012 (Fig. 5c). Generally, atmospheric aging makes aerosols more water-soluble during long-range transport (Aggarwal and Kawamura, 2009; Rudich et al., 2007; Robinson et al., 2007; Jimenez et al., 2009; Kawamura et al., 2010), especially in the remote marine atmosphere (Kawamura et al., 2003). This point is further supported by a decadal increase $\left(+0.08 \% \mathrm{yr}^{-1}\right)$ in the WSOC / OC ratios (Fig. 5f). These results may demonstrate that the increased concentrations of WSOC over the western North Pacific are significantly linked with increased photochemical aging of organic aerosols and oxidation of various VOCs during long-range atmospheric transport (Zhang et al., 2007; Decesari et al., 2010). An increasing trend of WSOC / TC $\left(p<0.05 ;+0.15 \% \mathrm{yr}^{-1}\right.$; Table 3 ) again suggests that photochemical formation of WSOC and its contributions to SOA have increased over the western North Pacific during 2001-2012. We observed an abrupt decrease in the WSOC / OC ratios between 2007 and 2008 (Fig. 5f), probably due to enhanced OC that may be caused by unknown sources. However, it should be noted that an observed decline in the WSOC / OC ratios does not affect the decadal trend even if those data are excluded from the trend analysis. 

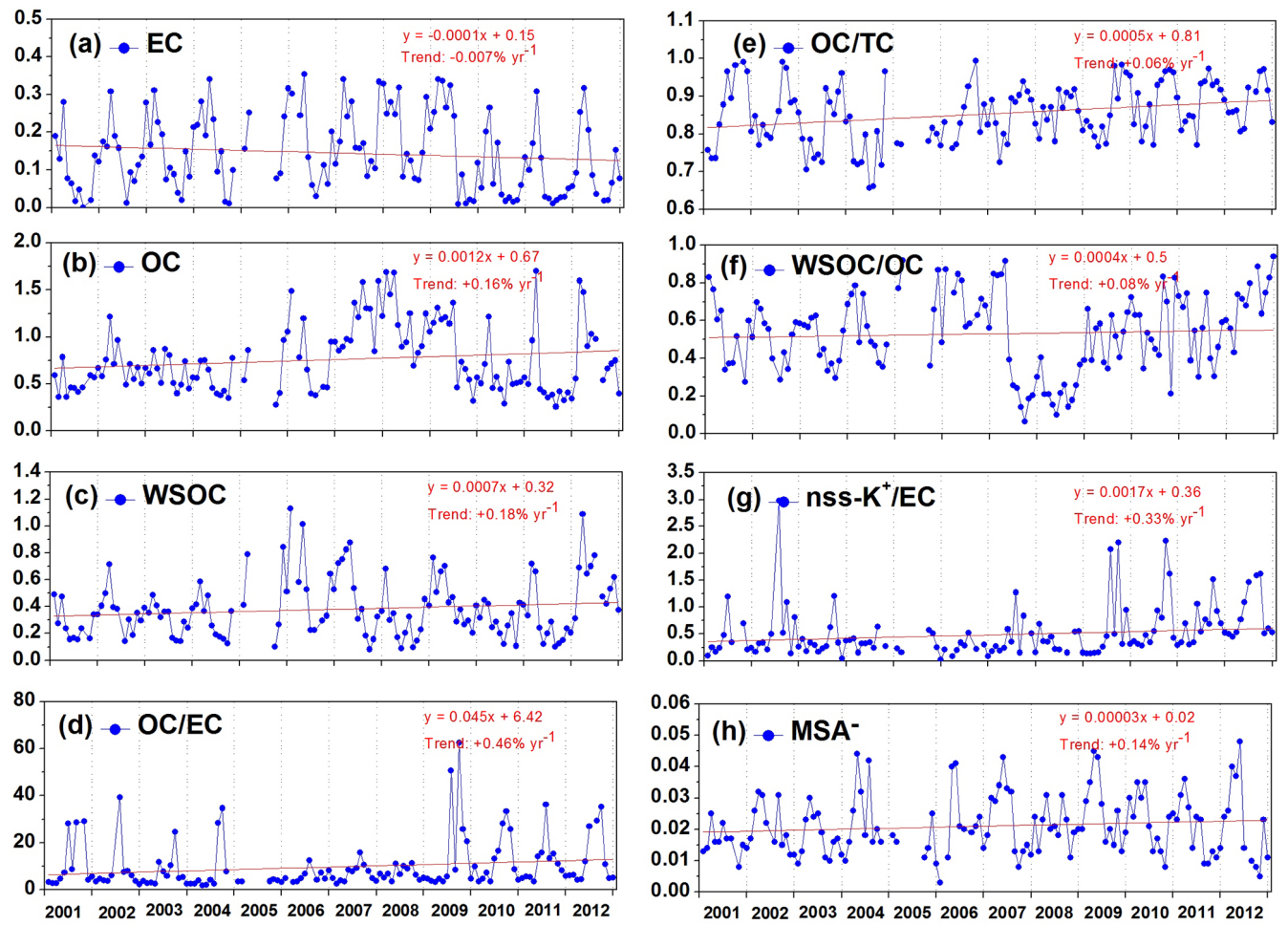

Figure 5. Annual trends (time series) in the concentrations $\left(\mu \mathrm{g} \mathrm{m}^{-3}\right)$ of carbonaceous aerosol components, water-soluble ionic tracer compound $\left(\mathrm{MSA}^{-}\right)$and some specific mass ratios during 2001-2012 over the western North Pacific. The linear trend equation $(y=m x+c)$ is also shown for the each annual trend.

To better understand the contributions of photochemical oxidation of biogenic VOCs to WSOC during longrange atmospheric transport, we present the annual trend of water-soluble organic ion, i.e., $\mathrm{MSA}^{-}$(a biogenic tracer; see Fig. 5h). In our previous study (Boreddy and Kawamura, 2015), we reported that $\mathrm{MSA}^{-}$significantly correlates with continental pollutants such as $\mathrm{NH}_{4}^{+}(r=0.56)$, nss- $\mathrm{K}^{+}(0.52)$ and nss-SO ${ }_{4}^{2-}(0.50)$ and no correlation with $\mathrm{Na}^{+}$, suggesting that continentally derived $\mathrm{MSA}^{-}$may be associated with the terrestrial higher plants and other biogenic sources along with Asian pollutants during the longrange transport. However, we should not ignore the oceanic biogenic emissions, especially in summer (Bikkina et al., 2014), although it has less abundance compared to continental biogenic emissions over the western North Pacific. In this study, the annual trend of $\mathrm{MSA}^{-}$showed a significant increase $\left(p<0.05 ;+0.14 \% \mathrm{yr}^{-1}\right)$ during 2001-2012, implying that continental transport of biogenic VOCs (BVOCs) over the western North Pacific have increased significantly during 2001-2012.

Zhang et al. (2016) reported an increase (from 132000 to $175000 \mathrm{tyr}^{-1}$ ) in the emission of isoprene in northern China during 1982-2010 using an emission model. Based on strong correlations $(r>0.90)$ between isoprene and abovecanopy temperature, they suggested that oxidations of biogenic BVOCs from the terrestrial higher plants are important in Asia (especially in China). Since Chichijima is an outflow region of East Asia, long-range atmospheric transport of BVOCs may be possible from terrestrial higher plants in Asia/China to the western North Pacific by westerly winds, which may significantly contribute to the enhanced trends of OC and WSOC during 2001-2012. We found significant $(p<0.05)$ increases in the annual trends of methylglyoxal and pyruvic acid, which are tracers of aqueous-phase oxidation of biogenic isoprene (Carlton et al., 2009), over the western North Pacific as shown in Fig. S3. We also found a moderate correlation $(r=0.40, p<0.01)$ between of $\mathrm{MSA}^{-}$and WSOC concentrations (not shown as a figure). These results demonstrate that the increase in WSOC is likely due to the increased photochemical oxidation of BVOCs during longrange transport over the western North Pacific in addition to the other emissions such as biomass burning.

\subsection{Atmospheric implications}

It is well known that atmospheric aerosols play a key role in the climate system as they can act as cloud condensation nuclei $(\mathrm{CCN})$ and impact on cloud formation and thus radiative forcing (RF) (IPCC, 2013). The RF of aerosol is generally estimated by using the aerosol optical depth (AOD), singlescattering albedo (SSA) and asymmetry parameter (Pani et al., 2016a). EC scatters the shortwave incoming solar radia- 

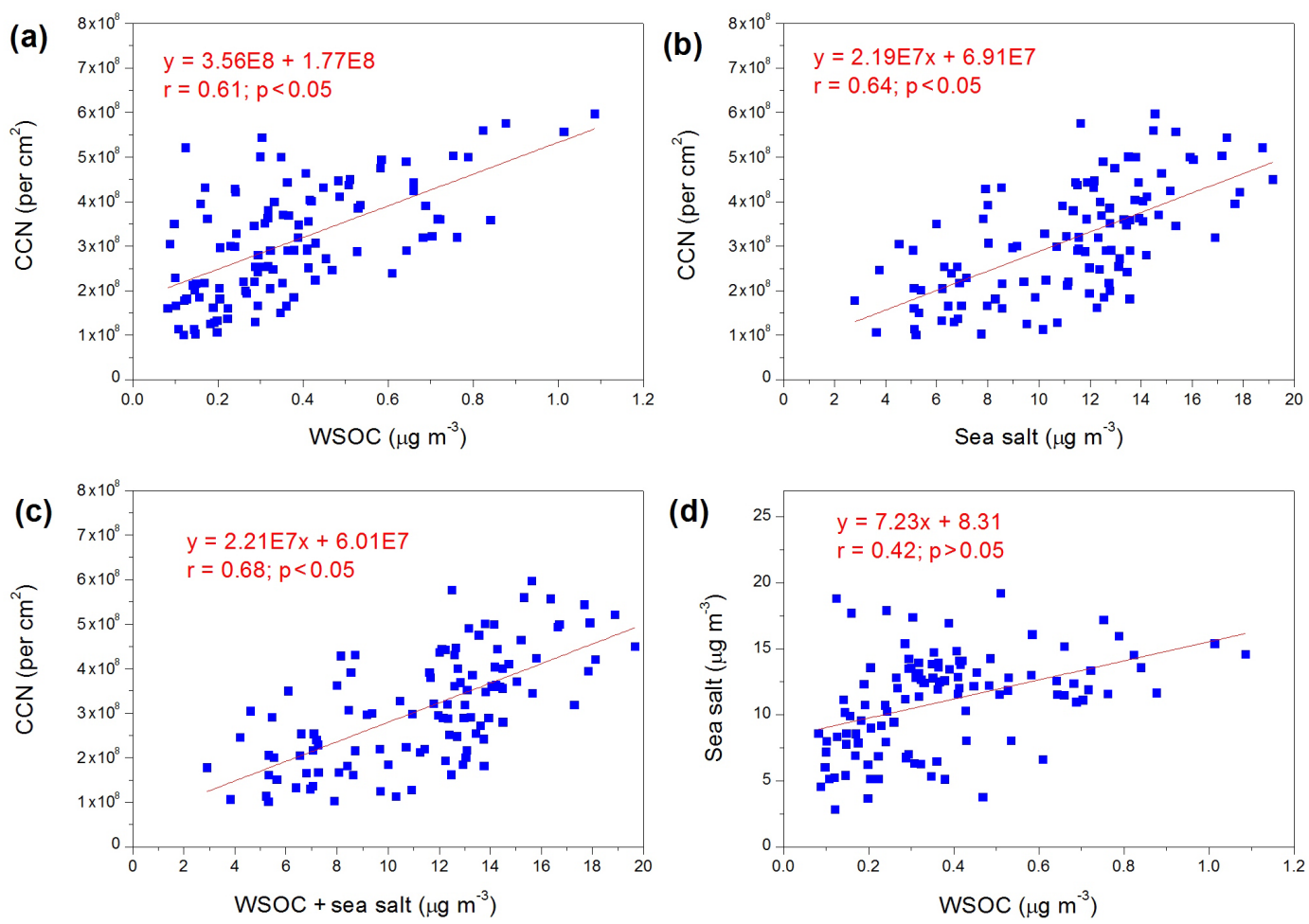

Figure 6. Regression analyses between (a) WSOC and MODIS-derived cloud condensation nuclei (CCN), (b) sea salt and CCN, (c) WSOC + sea salt and CCN, and (d) WSOC and sea salt concentrations over the western North Pacific.

tion less than OC, although it strongly absorbs the shortwave solar radiation as well as longwave outgoing terrestrial radiation in the atmosphere (Charlson et al., 1992; Ramanathan et al., 2001; Magi, 2009, 2011). The SSA, defined as the ratio of scattering to the extinction coefficient of aerosols, is an important property for determining the direct RF (Pani et al., 2016a, b). The SSA is highly sensitive to the nature (scattering and/or absorption) of aerosols in the atmosphere. Therefore, although OC has certain uncertainty because of light-absorbing brown carbon, OC / EC ratios can be used to understand the relative contributions of scattering or absorbing aerosols in the atmosphere.

Further, a good knowledge of the OC/EC ratios in aerosols (for example, biomass burning) may also help to improve model representation of the absorption caused by organic compounds constituting so-called brown carbon, which contributes to the aerosol RF (Chung et al., 2012; Saleh et al., 2014; Kirchstetter and Thatcher, 2012). In this study, atmospheric aging may make OC more scattering during long-range transport over the western North Pacific. An increasing trend of OC / EC ratios suggests that scattering aerosols are significantly increased over the western North Pacific. In contrast, absorbing aerosols may be decreased during the study period. This result may provide an important implication for radiative forcing because scattering and absorption coefficients are playing crucial role in the radiative forcing calculations as mentioned above.
Novakov and Corrigan (1996) found that pure organic components from biomass smoke emissions can form cloud condensation nuclei $(\mathrm{CCN})$ without the presence of sulfate $\left(\mathrm{SO}_{4}^{2-}\right)$ and other inorganic compounds. Roberts et al. (2002) showed that biomass-burning-derived organic aerosols do serve as CCN. Further, large loadings of CCN in continental air masses were observed over the western North Pacific (Matsumoto et al., 1997; Boreddy et al., 2015). In this study, the enhanced WSOC concentrations and WSOC / OC ratios in continental air masses suggest an important role of WSOC in $\mathrm{CCN}$ activity over the western North Pacific in addition to other aerosol constituents such as $\mathrm{SO}_{4}^{2-}$ and sea salts. To better understand the impact of WSOC on cloud-forming potential, we performed regression analyses between WSOC, sea salt and CCN concentrations as shown in Fig. 6. CCN data were downloaded from the MODIS satellite over the region $\left(140-145^{\circ}\right.$ E, $\left.25-30^{\circ} \mathrm{N}\right)$ in the western North Pacific for the period of July 2002 to December 2012.

The above results showed significantly good correlations ( $r=0.61$ and $0.64, p<0.05$ ) between WSOC versus CCN and sea salt versus CCN concentrations (Fig. 6a and b), suggesting the importance of WSOC for the formation of CCN over the western North Pacific in addition to sea salt. Further, the correlation coefficient between sea salt and $\mathrm{CCN}$ concentrations was slightly increased $(r=0.68 ; p<0.05)$ when WSOC was added to the sea salt as shown in Fig. 6c. Likely, the slope of the regression line between WSOC + sea 
salt and CCN was little higher (2.21E7) than the slope between sea salt and CCN (2.19E7). These results indicate that WSOC may slightly enhance the cloud-forming potential of sea salt, although it has less concentration over the western North Pacific. All these results suggest that a significant uncertainty exists in RF due to the contribution of water-soluble organic matter to cloud forming. Therefore, climate modelers should consider WSOC in addition to other factors (sea salts, sulfate, etc.), while calculating RF over the western North Pacific. This point is consistent with the previous studies, which explain the contribution of water-soluble organic matter to CCN (Matsumoto et al., 1997; Zhao et al., 2016).

It should be noted that all these ratios are applicable to organic fractions that are derived from the bulk parameters only; however, the size of particles also plays a role in RF as well as their morphology, chemical composition and mixing state (Jacobson, 2001; Lohmann and Feichter, 2005; R. Zhang et al., 2008). Although fine particles are important for CCN activation, physico-chemical processes (coagulation, condensation and other heterogeneous reactions) can make the particles from fine to coarse mode in aqueous phase, particularly over the marine atmosphere. Thus, bulk parameters of organic matter and its role in $\mathrm{CCN}$ activation are important in the remote marine atmosphere. Sea spray is not a major source of WSOC as inferred from Fig. 6d, which showed a moderate correlation $(r=0.42 ; p>0.05)$ between WSOC and sea salt during the study period. In this study, atmospheric processes or chemical aging makes OC more water-soluble during long-range transport over the western North Pacific as discussed in Sect. 3.2.

\section{Conclusions}

Based on the long-term (2001-2012) trends of carbonaceous aerosols from Chichijima in the western North Pacific, we conclude that seasonal variations of carbonaceous aerosols strictly followed seasonal trends of wind pattern at Chichijima in the western North Pacific. The annual trends of OC and WSOC with significant increases over the western North Pacific are probably due to the enhanced photochemical oxidation of biomass burning- and biogenic-derived VOCs during long-range atmospheric transport over the western North Pacific. This inference is supported by significant increases in the annual trends of OC/EC, WSOC/OC, OC/TC, WSOC / TC, nss- $\mathrm{K}^{+} / \mathrm{EC}$ mass ratios and $\mathrm{MSA}^{-}$concentrations. On the other hand, a decrease in the concentrations of EC during 2001-2012 suggests that the contribution of fossil-fuel-derived sources to carbonaceous aerosols may be decreased over the western North Pacific. Further, a good correlation $(r=0.61)$ between WSOC and CCN concentrations suggests that not only sea salt and nss- $\mathrm{SO}_{4}^{2-}$ but also water-soluble organic aerosols play a role in $\mathrm{CCN}$ formation. Therefore, the results from our study have important impli- cations toward the regional radiative balance, especially over the North Pacific.

Data availability. The MODIS fire data used in this study were acquired as part of NASA's Earth Science Enterprise (https://firms. modaps.eosdis.nasa.gov). Air mass back trajectories are downloaded from the NOAA-ARL website (http://www.arl.noaa.gov). The data used in this paper are available upon the request to the corresponding author (kkawamura@isc.chubu.ac.jp).

\section{The Supplement related to this article is available online at https://doi.org/10.5194/acp-18-1291-2018-supplement.}

Competing interests. The authors declare that they have no conflict of interest.

Acknowledgements. This work was supported by grants from the Japan Society for the Promotion of Science (JSPS, grantsin-aid nos. of 1920405 and 24221001). We are grateful for the financial support from the JSPS fellowship (ID no. PU16905) to Suresh K. R. Boreddy. The authors wish to thank the data distribution centers for their support. The authors also wish to thank the co-editor of the journal and the two anonymous reviewers for their constructive and useful comments, which improved the scientific content of the original paper.

Edited by: Stefania Gilardoni

Reviewed by: two anonymous referees

\section{References}

Aggarwal, S. G. and Kawamura, K.: Carbonaceous and inorganic composition in long-range transported aerosols over northern Japan: Implication for aging of water-soluble organic fraction, Atmos. Environ., 43, 2532-2540, 2009.

Andreae, M. O. and Merlet, P.: Emission of trace gases and aerosols from biomass burning, Global Biogeochem. Cy., 15, 955-966, 2001.

Asa-Awuku, A., Engelhart, G. J., Lee, B. H., Pandis, S. N., and Nenes, A.: Relating CCN activity, volatility, and droplet growth kinetics of $\beta$-caryophyllene secondary organic aerosol, Atmos. Chem. Phys., 9, 795-812, https://doi.org/10.5194/acp-9795-2009, 2009.

Bahadur, R., Praveen, P. S., Xu, Y., and Ramanathan, V.: Solar absorption by elemental and brown carbon determined from spectral observations, P. Natl. Acad Sci. USA, 109, 17366-17371, 2012.

Bikkina, S., Kawamura, K., Miyazaki, Y., and Fu, P.: High abundances of oxalic, azelaic and glyoxylic acids and methylglyoxal in the open ocean with high biological activity: Implication for secondary OA formation from isoprene, Geophys. Res. Lett., 41, 3649-3657, 2014 
Bond, T. C., Streets, D. G., Yarber, K. F., Nelson, S. M., Woo, J.-H., and Klimont, Z.: A technology-based global inventory of black and organic carbon emissions from combustion, J. Geophys. Res.-Atmos., 109, D14203, https://doi.org/10.1029/2003JD003697, 2004.

Bond, T. C., Doherty, S. J., Fahey, D. W., Forster, P. M., Berntsen, T., DeAngelo, B. J., Flanner, M. G., Ghan, S., Kärcher, B., Koch, D., Kinne, S., Kondo, Y., Quinn, P. K., Sarofim, M. C., Schultz, M. G., Schulz, M., Venkataraman, C., Zhang, H., Zhang, S., Bellouin, N., Guttikunda, S. K., Hopke, P. K., Jacobson, M. Z., Kaiser, J. W., Klimont, Z., Lohmann, U., Schwarz, J. P., Shindell, D., Storelvmo, T., Warren, S. G., and Zender, C. S.: Bounding the role of black carbon in the climate system: A scientific assessment, J. Geophys. Res.-Atmos., 118, 5380-5552, 2013.

Boreddy, S. K. R. and Kawamura, K.: A 12-year observation of water-soluble ions in TSP aerosols collected at a remote marine location in the western North Pacific: an outflow region of Asian dust, Atmos. Chem. Phys., 15, 6437-6453, https://doi.org/10.5194/acp-15-6437-2015, 2015.

Boreddy, S. K. R. and Kawamura, K.: Hygroscopic growth of watersoluble matter extracted from remote marine aerosols over the western North Pacific: Influence of pollutants transported from East Asia, Sci. Total Environ., 557-558, 285-295, 2016.

Boreddy, S. K. R., Kawamura, K., and Jung, J. S.: Hygroscopic properties of particles nebulized from water extracts of aerosols collected at Chichijima Island in the western North Pacific: An outflow region of Asian dust, J. Geophys. Res.-Atmos., 119, 167-178, 2014.

Boreddy, S. K. R., Kawamura, K., and Haque, M. M.: Long-term (2001-2012) observation of the modeled hygroscopic growth factor of remote marine TSP aerosols over the western North Pacific: impact of long-range transport of pollutants and their mixing states, Phys. Chem. Chem. Phys., 17, 29344-29353, 2015.

Boreddy, S. K. R., Kawamura, K., Bikkina, S., and Sarin, M. M.: Hygroscopic growth of particles nebulized from water-soluble extracts of $\mathrm{PM}_{2.5}$ aerosols over the Bay of Bengal: Influence of heterogeneity in air masses and formation pathways, Sci. Total Environ., 544, 661-669, 2016.

Boreddy, S. K. R., Kawamura, K., and Tachibana, E.: Long-term (2001-2013) observations of water-soluble dicarboxylic acids and related compounds over the western North Pacific: trends, seasonality and source apportionment, Scientific Reports, 7, 8518, https://doi.org/10.1038/s41598-017-08745-w, 2017.

Boucher, O., Randall, D., Artaxo, P., Bretherton, C., Feingold, G., Forster, P., Kerminen, V.-M., Kondo, Y., Liao, H., Lohmann, U., Rasch, P., Satheesh, S. K., Sherwood, S., Stevens, B., and Zhang, X. Y.: Clouds and Aerosols, in: Climate Change 2013: The Physical Science Basis. Contribution of Working Group I to the Fifth Assessment Report of the Intergovernmental Panel on Climate Change, edited by: Stocker, T. F., Qin, D., Plattner, G.-K., Tignor, M., Allen, S. K., Boschung, J., Nauels, A., Xia, Y., Bex, V., and Midgley, P. M., Cambridge University Press, Cambridge, UK and New York, NY, USA, 571-658, 2013.

Cachier, H., Bremond, M.-P., and Buat-Menard, P.: Carbonaceous aerosols from different tropical biomass burning sources, Nature, 340, 371-373, 1989.

Cao, G. L., Zhang, X. Y., and Zheng, F. C.: Inventory of black carbon and organic carbon emissions from China, Atmos. Environ., 40, 6516-6527, 2006.
Cao, J. J., Lee, S. C., Ho, K. F., Zhang, X. Y., Zou, S. C., Fung, K., Chow, J. C., and Watson, J. G.: Characteristics of carbonaceous aerosol on Pearl River Delta region, China during 2001 winter period, Atmos. Environ., 37, 1451-1460, 2003.

Cao, J. J., Wu, F., Chow, J. C., Lee, S. C., Li, Y., Chen, S. W., An, Z. S., Fung, K. K., Watson, J. G., Zhu, C. S., and Liu, S. X.: Characterization and source apportionment of atmospheric organic and elemental carbon during fall and winter of 2003 in Xi' an, China, Atmos. Chem. Phys., 5, 3127-3137, https://doi.org/10.5194/acp5-3127-2005, 2005.

Cao, J. J., Lee, S. C., Chow, J. C., Watson, J. G., Ho, K. F., Zhang, R. J., Jin, Z. D., Shen, Z. X., Chen, G. C., Kang, Y. M., Zou, S. C., Zhang, L. Z., Qi, S. H., Dai, M. H., Cheng, Y., and $\mathrm{Hu}, \mathrm{K}$.: Spatial and seasonal distributions of carbonaceous aerosols over China, J. Geophys. Res.-Atmos., 112, D22S11, https://doi.org/10.1029/2006JD008205, 2007.

Carlton, A. G., Wiedinmyer, C., and Kroll, J. H.: A review of Secondary Organic Aerosol (SOA) formation from isoprene, Atmos. Chem. Phys., 9, 4987-5005, https://doi.org/10.5194/acp-9-49872009, 2009.

Castro, L. M., Pio, C. A., Harrison, R. M., and Smith, D. J. T.: Carbonaceous aerosol in urban and rural European atmospheres: estimation of secondary organic carbon concentrations, Atmos. Environ., 33, 2771-2781, 1999.

Cazorla, A., Bahadur, R., Suski, K. J., Cahill, J. F., Chand, D., Schmid, B., Ramanathan, V., and Prather, K. A.: Relating aerosol absorption due to soot, organic carbon, and dust to emission sources determined from in-situ chemical measurements, Atmos. Chem. Phys., 13, 9337-9350, https://doi.org/10.5194/acp13-9337-2013, 2013.

Ceburnis, D., O’Dowd, C. D., Jennings, G. S., Facchini, M. C., Emblico, L., Decesari, S., Fuzzi, S., and Sakalys, J.: Marine aerosol chemistry gradients: Elucidating primary and secondary processes and fluxes, Geophys. Res. Lett., 35, L07804, https://doi.org/10.1029/2008GL033462, 2008.

Charlson, R. J., Schwartz, S. E., Hales, J. M., Cess, R. D., Coakley, J. A., Hansen, J. E., and Hofmann, D. J.: Climate forcing by anthropogenic aerosols, Science, 255, 423-430, 1992.

Cheung, K. L., Polidori, A., Ntziachristos, L., Tzamkiozis, T., Samaras, Z., Cassee, F. R., Gerlofs, M., and Sioutas, C.: Chemical Characteristics and Oxidative Potential of Particulate Matter Emissions from Gasoline, Diesel, and Biodiesel Cars, Environ. Sci. Technol., 43, 6334-6340, 2009.

Chow, J. C. and Watson, J. G.: $\mathrm{PM}_{2.5}$ carbonate concentrations at regionally representative Interagency Monitoring of Protected Visual Environment sites, J. Geophys. Res.-Atmos., 107, 8344, https://doi.org/10.1029/2001JD000574, 2002.

Chow, J. C., Watson, J. G., Lu, Z., Lowenthal, D. H., Frazier, C. A., Solomon, P. A., Thuillier, R. H., and Magliano, K.: Descriptive analysis of $\mathrm{PM}_{2.5}$ and $\mathrm{PM}_{10}$ at regionally representative locations during SJVAQS/AUSPEX, Atmos. Environ., 30, 20792112, 1996.

Chow, J. C., Watson, J. G., Crow, D., Lowenthal, D. H., and Merrifield, T.: Comparison of IMPROVE and NIOSH Carbon Measurements, Aerosol. Sci. Tech., 34, 23-34, 2001.

Chung, C. E., Ramanathan, V., and Decremer, D.: Observationally constrained estimates of carbonaceous aerosol radiative forcing, P. Natl. Acad. Sci. USA, 109, 11624-11629, 2012. 
Chung, S. H. and Seinfeld, J. H.: Global distribution and climate forcing of carbonaceous aerosols, J. Geophys. Res.-Atmos., 107, 4407, https://doi.org/10.1029/2001JD001397, 2002.

Clarke, A. G. and Karani, G. N.: Characterisation of the carbonate content of atmospheric aerosols, J. Atmos. Chem., 14, 119-128, 1992.

Cui, H., Mao, P., Zhao, Y., Nielsen, C. P., and Zhang, J.: Patterns in atmospheric carbonaceous aerosols in China: emission estimates and observed concentrations, Atmos. Chem. Phys., 15, 86578678, https://doi.org/10.5194/acp-15-8657-2015, 2015.

Dallmann, T. R., Onasch, T. B., Kirchstetter, T. W., Worton, D. R., Fortner, E. C., Herndon, S. C., Wood, E. C., Franklin, J. P., Worsnop, D. R., Goldstein, A. H., and Harley, R. A.: Characterization of particulate matter emissions from on-road gasoline and diesel vehicles using a soot particle aerosol mass spectrometer, Atmos. Chem. Phys., 14, 7585-7599, https://doi.org/10.5194/acp-14-7585-2014, 2014.

Decesari, S., Facchini, M. C., Matta, E., Lettini, F., Mircea, M., Fuzzi, S., Tagliavini, E., and Putaud, J. P.: Chemical features and seasonal variation of fine aerosol water-soluble organic compounds in the Po Valley, Italy, Atmos. Environ., 35, 3691-3699, 2001.

Decesari, S., Facchini, M. C., Carbone, C., Giulianelli, L., Rinaldi, M., Finessi, E., Fuzzi, S., Marinoni, A., Cristofanelli, P., Duchi, R., Bonasoni, P., Vuillermoz, E., Cozic, J., Jaffrezo, J. L., and Laj, P.: Chemical composition of $\mathrm{PM}_{10}$ and $\mathrm{PM}_{1}$ at the highaltitude Himalayan station Nepal Climate Observatory-Pyramid (NCO-P) (5079 m a.s.1.), Atmos. Chem. Phys., 10, 4583-4596, https://doi.org/10.5194/acp-10-4583-2010, 2010.

Docherty, K. S., Stone, E. A., Ulbrich, I. M., DeCarlo, P. F., Snyder, D. C., Schauer, J. J., Peltier, R. E., Weber, R. J., Murphy, S. M., Seinfeld, J. H., Grover, B. D., Eatough, D. J., and Jimenez, J. L.: Apportionment of Primary and Secondary Organic Aerosols in Southern California during the 2005 Study of Organic Aerosols in Riverside (SOAR-1), Environ. Sci. Technol., 42, 7655-7662, 2008.

Draper, N. R. and Smith, H.: Applied Regression Analysis, 3rd Edn., Wiley, New York, 1966.

Draxler, R. R. and Rolph, G. D.: HYSPLIT (HYbrid Single-Particle Lagrangian Integrated Trajectory) Model, access via NOAA ARL READY Website, available at: https://ready.arl.noaa.gov/ HYSPLIT_traj.php (last access: October 2017), 2013.

Duce, R. A., Unni, C. K., Ray, B. J., Prospero, J. M., and Merrill, J. T.: Long-range atmospheric transport of soil dust from Asia to the tropical North Pacific: Temporal variability, Science, 209, 1522-1524, 1980.

Facchini, M. C., Rinaldi, M., Decesari, S., Carbone, C., Finessi, E., Mircea, M., Fuzzi, S., Ceburnis, D., Flagan, R., Nilsson, E. D., de Leeuw, G., Martino, M., Woeltjen, J., and O'Dowd, C. D.: Primary submicron marine aerosol dominated by insoluble organic colloids and aggregates, Geophys. Res. Lett., 35, L17814, https://doi.org/10.1029/2008GL034210, 2008.

Fatima, H., Upadhyaya, H. C., and Sharma, O. P.: Sensitivity of radiative forcing to global carbonaceous emissions, 64, 17157, https://doi.org/10.3402/tellusb.v64i0.17157, 2012.

Feng, Y., Ramanathan, V., and Kotamarthi, V. R.: Brown carbon: a significant atmospheric absorber of solar radiation?, Atmos. Chem. Phys., 13, 8607-8621, https://doi.org/10.5194/acp13-8607-2013, 2013.
Fu, T.-M., Cao, J. J., Zhang, X. Y., Lee, S. C., Zhang, Q., Han, Y. M., Qu, W. J., Han, Z., Zhang, R., Wang, Y. X., Chen, D., and Henze, D. K.: Carbonaceous aerosols in China: top-down constraints on primary sources and estimation of secondary contribution, Atmos. Chem. Phys., 12, 2725-2746, https://doi.org/10.5194/acp12-2725-2012, 2012.

Gondwe, M., Krol, M., Klaassen, W., Gieskes, W., and de Baar, H.: Comparison of modelled versus measured MSA : nss-SO $\mathrm{SO}_{4}^{2-}$ ratios: A Global analysis, Global Biogeochem. Cy., 18, GB2006, https://doi.org/10.1029/2003GB002144, 2004.

Graham, B., Mayol-Bracero, O. L., Guyon, P., Roberts, G. C., Decesari, S., Facchini, M. C., Artaxo, P., Maenhaut, W., Koll, P., and Andreae, M. O.: Water-soluble organic compounds in biomass burning aerosols over Amazonia 1. Characterization by NMR and GC-MS, J. Geophys. Res.-Atmos., 107, LBA 14-1-LBA 1416, https://doi.org/10.1029/2001JD000336, 2002.

Huang, K., Fu, J. S., Hsu, N. C., Gao, Y., Dong, X., Tsay, S.-C., and Lam, Y. F.: Impact assessment of biomass burning on air quality in Southeast and East Asia during BASE-ASIA, Atmos. Environ., 78, 291-302, 2013.

IPCC: Climate Change 2013: The Physical Science Basis. Contribution of Working Group I to the Fifth Assessment Report of the Intergovernmental Panel on Climate Change, Cambridge University Press, Cambridge, UK and New York, NY, USA, 1535 pp., 2013.

Jacobson, M. Z.: Strong radiative heating due to the mixing state of black carbon in atmospheric aerosols, Nature, 409, 695-697, 2001.

Jimenez, J. L., Canagaratna, M. R., Donahue, N. M., Prevot, A. S. H., Zhang, Q., Kroll, J. H., DeCarlo, P. F., Allan, J. D., Coe, H., Ng, N. L., Aiken, A. C., Docherty, K. S., Ulbrich, I. M., Grieshop, A. P., Robinson, A. L., Duplissy, J., Smith, J. D., Wilson, K. R., Lanz, V. A., Hueglin, C., Sun, Y. L., Tian, J., Laaksonen, A., Raatikainen, T., Rautiainen, J., Vaattovaara, P., Ehn, M., Kulmala, M., Tomlinson, J. M., Collins, D. R., Cubison, M. J., Dunlea, E. J., Huffman, J. A., Onasch, T. B., Alfarra, M. R., Williams, P. I., Bower, K., Kondo, Y., Schneider, J., Drewnick, F., Borrmann, S., Weimer, S., Demerjian, K., Salcedo, D., Cottrell, L., Griffin, R., Takami, A., Miyoshi, T., Hatakeyama, S., Shimono, A., Sun, J. Y., Zhang, Y. M., Dzepina, K., Kimmel, J. R., Sueper, D., Jayne, J. T., Herndon, S. C., Trimborn, A. M., Williams, L. R., Wood, E. C., Middlebrook, A. M., Kolb, C. E., Baltensperger, U., and Worsnop, D. R.: Evolution of organic aerosols in the atmosphere, Science, 326, 1525-1529, 2009.

Kanakidou, M., Seinfeld, J. H., Pandis, S. N., Barnes, I., Dentener, F. J., Facchini, M. C., Van Dingenen, R., Ervens, B., Nenes, A., Nielsen, C. J., Swietlicki, E., Putaud, J. P., Balkanski, Y., Fuzzi, S., Horth, J., Moortgat, G. K., Winterhalter, R., Myhre, C. E. L., Tsigaridis, K., Vignati, E., Stephanou, E. G., and Wilson, J.: Organic aerosol and global climate modelling: a review, Atmos. Chem. Phys., 5, 1053-1123, https://doi.org/10.5194/acp-5-10532005, 2005.

Kawamura, K. and Sakaguchi, F.: Molecular distributions of water soluble dicarboxylic acids in marine aerosols over the Pacific Ocean including tropics, J. Geophys. Res.-Atmos., 104, 35013509, 1999.

Kawamura, K., Ishimura, Y., and Yamazaki, K.: Four years' observations of terrestrial lipid class compounds in marine aerosols 
from the western North Pacific, Global Biogeochem. Cy., 17, 1003, https://doi.org/10.1029/2001GB001810, 2003.

Kawamura, K., Kasukabe, H., and Barrie, L. A.: Secondary formation of water-soluble organic acids and $\alpha$-dicarbonyls and their contributions to total carbon and water-soluble organic carbon: Photochemical aging of organic aerosols in the Arctic spring, J. Geophys. Res.-Atmos., 115, D21306, https://doi.org/10.1029/2010jd014299, 2010.

Keene, W. C., Maring, H., Maben, J. R., Kieber, D. J., Pszenny, A. A. P., Dahl, E. E., Izaguirre, M. A., Davis, A. J., Long, M. S., Zhou, X., Smoydzin, L., and Sander, R.: Chemical and physical characteristics of nascent aerosols produced by bursting bubbles at a model air-sea interface, J. Geophys. Res.-Atmos., 112, D21202, https://doi.org/10.1029/2007JD008464, 2007.

Kendall, M. G.: Rank Correlation Methods, Griffin, London, 1975.

Kirchstetter, T. W. and Thatcher, T. L.: Contribution of organic carbon to wood smoke particulate matter absorption of solar radiation, Atmos. Chem. Phys., 12, 6067-6072, https://doi.org/10.5194/acp-12-6067-2012, 2012.

Kirillova, E. N., Andersson, A., Han, J., Lee, M., and Gustafsson, Ö.: Sources and light absorption of water-soluble organic carbon aerosols in the outflow from northern China, Atmos. Chem. Phys., 14, 1413-1422, https://doi.org/10.5194/acp-141413-2014, 2014

Koch, D.: Transport and direct radiative forcing of carbonaceous and sulfate aerosols in the GISS GCM, J. Geophys. Res.-Atmos., 106, 20311-20332, 2001.

Kondo, Y., Miyazaki, Y., Takegawa, N., Miyakawa, T., Weber, R. J., Jimenez, J. L., Zhang, Q., and Worsnop, D. R.: Oxygenated and water-soluble organic aerosols in Tokyo, J. Geophys. Res.Atmos., 112, D01203, https://doi.org/10.1029/2006JD007056, 2007.

Kunwar, B. and Kawamura, K.: One-year observations of carbonaceous and nitrogenous components and major ions in the aerosols from subtropical Okinawa Island, an outflow region of Asian dusts, Atmos. Chem. Phys., 14, 1819-1836, https://doi.org/10.5194/acp-14-1819-2014, 2014.

Laskin, A., Laskin, J., and Nizkorodov, S. A.: Chemistry of Atmospheric Brown Carbon, Chem. Rev., 115, 4335-4382, 2015.

Lin, N.-H., Tsay, S.-C., Maring, H. B., Yen, M.-C., Sheu, G.-R., Wang, S.-H., Chi, K. H., Chuang, M.-T., Ou-Yang, C.-F., Fu, J. S., Reid, J. S., Lee, C.-T., Wang, L.-C., Wang, J.-L., Hsu, C. N., Sayer, A. M., Holben, B. N., Chu, Y.-C., Nguyen, X. A., Sopajaree, K., Chen, S.-J., Cheng, M.-T., Tsuang, B.-J., Tsai, C.-J., Peng, C.-M., Schnell, R. C., Conway, T., Chang, C.-T., Lin, K.S., Tsai, Y. I., Lee, W.-J., Chang, S.-C., Liu, J.-J., Chiang, W.-L., Huang, S.-J., Lin, T.-H., and Liu, G.-R.: An overview of regional experiments on biomass burning aerosols and related pollutants in Southeast Asia: From BASE-ASIA and the Dongsha Experiment to 7-SEAS, Atmos. Environ., 78, 1-19, 2013.

Lohmann, U. and Feichter, J.: Global indirect aerosol effects: a review, Atmos. Chem. Phys., 5, 715-737, https://doi.org/10.5194/acp-5-715-2005, 2005.

Lu, Z., Streets, D. G., Zhang, Q., Wang, S., Carmichael, G. R., Cheng, Y. F., Wei, C., Chin, M., Diehl, T., and Tan, Q.: Sulfur dioxide emissions in China and sulfur trends in East Asia since 2000, Atmos. Chem. Phys., 10, 6311-6331, https://doi.org/10.5194/acp-10-6311-2010, 2010.
Lu, Z., Zhang, Q., and Streets, D. G.: Sulfur dioxide and primary carbonaceous aerosol emissions in China and India, 1996-2010, Atmos. Chem. Phys., 11, 9839-9864, https://doi.org/10.5194/acp-11-9839-2011, 2011.

Lu, Z., Streets, D. G., Winijkul, E., Yan, F., Chen, Y., Bond, T. C., Feng, Y., Dubey, M. K., Liu, S., Pinto, J. P., and Carmichael, G. R.: Light Absorption Properties and Radiative Effects of Primary Organic Aerosol Emissions, Environ. Sci. Technol., 49, 48684877, 2015.

Magi, B. I.: Chemical apportionment of southern African aerosol mass and optical depth, Atmos. Chem. Phys., 9, 7643-7655, https://doi.org/10.5194/acp-9-7643-2009, 2009.

Magi, B. I.: Corrigendum to "Chemical apportionment of southern African aerosol mass and optical depth" published in Atmos. Chem. Phys., 9, 7643-7655, 2009, Atmos. Chem. Phys., 11, 4777-4778, https://doi.org/10.5194/acp-11-4777-2011, 2011.

Mann, H. B.: Nonparametric Tests Against Trend, Econometrica, 13, 245-259, 1945.

Matsumoto, K., Tanaka, H., Nagao, I., and Ishizaka, Y.: Contribution of particulate sulfate and organic carbon to cloud condensation nuclei in the marine atmosphere, Geophys. Res. Lett., 24, 655-658, 1997.

Matsumoto, K., Uyama, Y., Hayano, T., and Uematsu, M.: Transport and chemical transformation of anthropogenic and mineral aerosol in the marine boundary layer over the western North Pacific Ocean, J. Geophys. Res.-Atmos., 109, D21206, https://doi.org/10.1029/2004JD004696, 2004.

Menon, S., Hansen, J., Nazarenko, L., and Luo, Y.: Climate effects of black carbon aerosols in China and India, Science, 297, 22502253, 2002.

Miyazaki, Y., Kondo, Y., Han, S., Koike, M., Kodama, D., Komazaki, Y., Tanimoto, H., and Matsueda, H.: Chemical characteristics of water-soluble organic carbon in the Asian outflow, J. Geophys. Res.-Atmos., 112, D22S30, https://doi.org/10.1029/2007JD009116, 2007.

Miyazaki, Y., Kawamura, K., and Sawano, M.: Size distributions and chemical characterization of water-soluble organic aerosols over the western North Pacific in summer, J. Geophys. Res.Atmos., 115, D23210, https://doi.org/10.1029/2010jd014439, 2010.

Miyazaki, Y., Kawamura, K., Jung, J., Furutani, H., and Uematsu, M.: Latitudinal distributions of organic nitrogen and organic carbon in marine aerosols over the western North Pacific, Atmos. Chem. Phys., 11, 3037-3049, https://doi.org/10.5194/acp11-3037-2011, 2011.

Mochida, M., Kawabata, A., Kawamura, K., Hatsushika, H., and Yamazaki, K.: Seasonal variation and origins of dicarboxylic acids in the marine atmosphere over the western North Pacific, J. Geophys. Res.-Atmos., 108, 4193, https://doi.org/10.1029/2002JD002355, 2003.

Na, K., Sawant, A. A., Song, C., and Cocker III, D. R.: Primary and secondary carbonaceous species in the atmosphere of Western Riverside County, California, Atmos. Environ., 38, 1345-1355, 2004.

Novakov, T. and Corrigan, C. E.: Cloud condensation nucleus activity of the organic component of biomass smoke particles, Geophys. Res. Lett., 23, 2141-2144, 1996. 
Novakov, T. and Penner, J. E.: Large contribution of organic aerosols to cloud-condensation-nuclei concentrations, Nature, 365, 823-826, 1993.

Ovadnevaite, J., O'Dowd, C., Dall'Osto, M., Ceburnis, D., Worsnop, D. R., and Berresheim, H.: Detecting high contributions of primary organic matter to marine aerosol: A case study, Geophys. Res. Lett., 38, L02807, https://doi.org/10.1029/2010gl046083, 2011.

Pani, S. K., Wang, S.-H., Lin, N.-H., Tsay, S.-C., Lolli, S., Chuang, M.-T., Lee, C.-T., Chantara, S., and Yu, J.-Y.: Assessment of aerosol optical property and radiative effect for the layer decoupling cases over the northern South China Sea during the 7-SEAS/Dongsha Experiment, J. Geophys. Res.-Atmos., 121, 4894-4906, 2016a.

Pani, S. K., Wang, S. H., Lin, N. H., Lee, C. T.,Tsay, S. C., Holben, B. N., Janjai, S., Hsiao, T. C., Chuang, M. T., and Chantara, S.: Radiative effects of springtime biomass-burning aerosols over Northern Indichina during 7-SEAS/BASELInE 2013 campaign, Aerosol Air Qual. Res., 16, 2802-2817, 2016 b.

Pani, S. K., Lee, C. T., Chou, C. C. K., Shimada, K., Hatakeyama, S., Takami, A., Wang, S. H., and Lin, N. H.: Chemical Characterization of Wintertime Aerosols over Islands and Mountains in East Asia: Impacts of the Continental Asian Outflow, Aerosol Air Qual. Res., 17, 3006-3036, https://doi.org/10.4209/aaqr.2017.03.0097, 2017.

Pöschl, U.: Atmospheric aerosols: Composition, transformation, climate and health effects, Angew. Chem. Int. Ed., 44, 7520 7540, 2005.

Ram, K. and Sarin, M. M.: Day-night variability of EC, OC, WSOC and inorganic ions in urban environment of Indo-Gangetic Plain: Implications to secondary aerosol formation, Atmos. Environ., 45, 460-468, 2011.

Ram, K. and Sarin, M. M.: Carbonaceous Aerosols Over Northern India: Sources and Spatio-temporal Variability, Proceedings of the Indian National Science Academy, 78, 523-533, 2012.

Ram, K., Sarin, M. M., and Hegde, P.: Long-term record of aerosol optical properties and chemical composition from a highaltitude site (Manora Peak) in Central Himalaya, Atmos. Chem. Phys., 10, 11791-11803, https://doi.org/10.5194/acp-10-117912010, 2010a.

Ram, K., Sarin, M. M., and Tripathi, S. N.: A 1 year record of carbonaceous aerosols from an urban site in the Indo-Gangetic Plain: Characterization, sources, and temporal variability, J. Geophys. Res., 115, D24313, https://doi.org/10.1029/2010jd014188, 2010b.

Ramanathan, V. and Carmichael, G.: Global and regional climate changes due to black carbon, Nat. Geosci., 1, 221-227, 2008.

Ramanathan, V., Crutzen, P. J., Kiehl, J. T., and Rosenfeld, D.: Atmosphere - Aerosols, climate, and the hydrological cycle, Science, 294, 2119-2124, 2001.

Rastogi, N., Singh, A., Sarin, M. M., and Singh, D.: Temporal variability of primary and secondary aerosols over northern India: Impact of biomass burning emissions, Atmos. Environ. B-Urb., 125, 396-403, 2016.

Reddy, M. S. and Boucher, O.: A study of the global cycle of carbonaceous aerosols in the LMDZT general circulation model, J. Geophys. Res.-Atmos., 109, D14202, https://doi.org/10.1029/2003JD004048, 2004.
Roberts, G. C., Artaxo, P., Zhou, J., Swietlicki, E., and Andreae, M. O.: Sensitivity of CCN spectra on chemical and physical properties of aerosol: A case study from the Amazon Basin, J. Geophys. Res.-Atmos., 107, LBA 37-1-LBA 37-18, https://doi.org/10.1029/2001JD000583, 2002.

Robinson, A. L., Donahue, N. M., Shrivastava, M. K., Weitkamp, E. A., Sage, A. M., Grieshop, A. P., Lane, T. E., Pierce, J. R., and Pandis, S. N.: Rethinking organic aerosols: Semivolatile emissions and photochemical aging, Science, 315, 1259-1262, 2007.

Rudich, Y., Donahue, N. M., and Mentel, T. F.: Aging of organic aerosol: Bridging the gap between laboratory and field studies, Annu. Rev. Phys. Chem., 58, 321-352, 2007.

Saarikoski, S., Timonen, H., Saarnio, K., Aurela, M., Järvi, L., Keronen, P., Kerminen, V.-M., and Hillamo, R.: Sources of organic carbon in fine particulate matter in northern European urban air, Atmos. Chem. Phys., 8, 6281-6295, https://doi.org/10.5194/acp-8-6281-2008, 2008.

Saleh, R., Robinson, E. S., Tkacik, D. S., Ahern, A. T., Liu, S., Aiken, A. C., Sullivan, R. C., Presto, A. A., Dubey, M. K., Yokelson, R. J., Donahue, N. M., and Robinson, A. L.: Brownness of organics in aerosols from biomass burning linked to their black carbon content, Nat. Geosci., 7, 647-650, 2014.

Sannigrahi, P., Sullivan, A. P., Weber, R. J., and Ingall, E. D.: Characterization of Water-Soluble Organic Carbon in Urban Atmospheric Aerosols Using Solid-State 13C NMR Spectroscopy, Environ. Sci. Technol., 40, 666-672, 2006.

Savoie, D. L. and Prospero, J. M.: comparison of oceanic and continental sources of non-sea-salt sulphate over the Pacific Ocean, Nature, 339, 685-687, 1989.

Scholes, M. and Andreae, M. O.: Biogenic and Pyrogenic Emissions from Africa and Their Impact on the Global Atmosphere, Ambio, 29, 23-29, 2000.

See, S. W. and Balasubramanian, R.: Chemical characteristics of fine particles emitted from different gas cooking methods, Atmos. Environ., 42, 8852-8862, 2008.

Simoneit, B. R. T.: Biomass burning-a review of organic tracers for smoke from incomplete combustion, Appl. Geochem., 17, 129$162,2002$.

Snyder, D. C., Rutter, A. P., Collins, R., Worley, C., and Schauer, J. J.: Insights into the Origin of Water Soluble Organic Carbon in Atmospheric Fine Particulate Matter, Aerosol. Sci. Tech., 43, 1099-1107, 2009.

Stavrakou, T., Müller, J.-F., Bauwens, M., De Smedt, I., Van Roozendael, M., Guenther, A., Wild, M., and Xia, X.: Isoprene emissions over Asia 1979-2012: impact of climate and land-use changes, Atmos. Chem. Phys., 14, 4587-4605, https://doi.org/10.5194/acp-14-4587-2014, 2014.

Sudheer, A. K., Rengarajan, R., and Sheel, V.: Secondary organic aerosol over an urban environment in a semi-arid region of western India, Atmos. Pollut. Res., 6, 11-20, 2015.

Szidat, S., Jenk, T. M., Synal, H.-A., Kalberer, M., Wacker, L., Hajdas, I., Kasper-Giebl, A., and Baltensperger, U.: Contributions of fossil fuel, biomass-burning, and biogenic emissions to carbonaceous aerosols in Zurich as traced by ${ }^{14} \mathrm{C}$, J. Geophys. Res.Atmos., 111, D07206, https://doi.org/10.1029/2005JD006590, 2006.

Tsay, S. C., Maring, H. B., Lin, N. H., Buntoung, S., Chantara, S., Chuang, H. C., Gabriel, P. M., Goodloe, C. S., Holben, B. N., Hsiao, T. C., Hsu, N. C., Janjai, S., Lau, W. K. M., Lee, C. T., 
Lee, J., Loftus, A. M., Nguyen, A. X., Nguyen, C. M., Pani, S. K., Pantina, P., Sayer, A. M., Tao, W. K., Wang, S. H., Welton, E. J., Wiriya, W., and Yen, M. C.: Satellite-Surface Perspectives of Air Quality and Aerosol-Cloud Effects on the Environment: An Overview of 7-SEAS/BASELInE, Aerosol Air Qual. Res., 16, 2581-2602, 2016.

Turpin, B. J. and Huntzicker, J. J.: Identification of secondary organic aerosol episodes and quantitation of primary and secondary organic aerosol concentrations during SCAQS, Atmos. Environ., 29, 3527-3544, 1995.

Verma, S. K., Kawamura, K., Chen, J., Fu, P., and Zhu, C.: Thirteen years of observations on biomass burning organic tracers over Chichijima Island in the western North Pacific: An outflow region of Asian aerosols, J. Geophys. Res.-Atmos., 120, 41554168, 2015.

Wang, H., Kawamura, K., and Shooter, D.: Carbonaceous and ionic components in wintertime atmospheric aerosols from two New Zealand cities: Implications for solid fuel combustion, Atmos. Environ., 39, 5865-5875, 2005.

Wang, L., Zhou, X., Ma, Y., Cao, Z., Wu, R., and Wang, W.: Carbonaceous aerosols over China - review of observations, emissions, and climate forcing, Environ. Sci. Pollut. R., 23, 16711680, 2016.

Watson, J. G., Chow, J. C., and Houck, J. E.: PM 2.5 chemical source profiles for vehicle exhaust, vegetative burning, geological material, and coal burning in Northwestern Colorado during 1995, Chemosphere, 43, 1141-1151, 2001.

Weber, R. J., Sullivan, A. P., Peltier, R. E., Russell, A., Yan, B., Zheng, M., de Gouw, J., Warneke, C., Brock, C., Holloway, J. S., Atlas, E. L., and Edgerton, E.: A study of secondary organic aerosol formation in the anthropogenic-influenced southeastern United States, J. Geophys. Res.-Atmos., 112, D11302, https://doi.org/10.1029/2007JD008408, 2007.

Youn, J.-S., Wang, Z., Wonaschütz, A., Arellano, A., Betterton, E. A., and Sorooshian, A.: Evidence of aqueous secondary organic aerosol formation from biogenic emissions in the North American Sonoran Desert, Geophys. Res. Lett., 40, 3468-3472, 2013.
Zhang, Q., Jimenez, J. L., Canagaratna, M. R., Allan, J. D., Coe, H., Ulbrich, I., Alfarra, M. R., Takami, A., Middlebrook, A. M., Sun, Y. L., Dzepina, K., Dunlea, E., Docherty, K., DeCarlo, P. F., Salcedo, D., Onasch, T., Jayne, J. T., Miyoshi, T., Shimono, A., Hatakeyama, S., Takegawa, N., Kondo, Y., Schneider, J., Drewnick, F., Borrmann, S., Weimer, S., Demerjian, K., Williams, P., Bower, K., Bahreini, R., Cottrell, L., Griffin, R. J., Rautiainen, J., Sun, J. Y., Zhang, Y. M., and Worsnop, D. R.: Ubiquity and dominance of oxygenated species in organic aerosols in anthropogenically-influenced Northern Hemisphere midlatitudes, Geophys. Res. Lett., 34, L13801, https://doi.org/10.1029/2007GL029979, 2007.

Zhang, R., Khalizov, A. F., Pagels, J., Zhang, D., Xue, H., and McMurry, P. H.: Variability in morphology, hygroscopicity, and optical properties of soot aerosols during atmospheric processing, P. Natl. Acad. Sci. USA, 105, 10291-10296, 2008.

Zhang, X., Huang, T., Zhang, L., Shen, Y., Zhao, Y., Gao, H., Mao, X., Jia, C., and Ma, J.: Three-North Shelter Forest Program contribution to long-term increasing trends of biogenic isoprene emissions in northern China, Atmos. Chem. Phys., 16, 69496960, https://doi.org/10.5194/acp-16-6949-2016, 2016.

Zhang, X. Y., Wang, Y. Q., Zhang, X. C., Guo, W., and Gong, S. L.: Carbonaceous aerosol composition over various regions of China during 2006, J. Geophys. Res.-Atmos., 113, D14111, https://doi.org/10.1029/2007JD009525, 2008.

Zhang, Y.-L. and Cao, F.: Fine particulate matter $\left(\mathrm{PM}_{2.5}\right)$ in China at a city level, Scientific Reports, 5, 14884, https://doi.org/10.1038/srep14884, 2015.

Zhao, D. F., Buchholz, A., Kortner, B., Schlag, P., Rubach, F., Fuchs, H., Kiendler-Scharr, A., Tillmann, R., Wahner, A., Watne, Å. K., Hallquist, M., Flores, J. M., Rudich, Y., Kristensen, K., Hansen, A. M. K., Glasius, M., Kourtchev, I., Kalberer, M., and Mentel, Th. F.: Cloud condensation nuclei activity, droplet growth kinetics, and hygroscopicity of biogenic and anthropogenic secondary organic aerosol (SOA), Atmos. Chem. Phys., 16, 1105-1121, https://doi.org/10.5194/acp16-1105-2016, 2016. 